\title{
LAWYERS SUING LAW FIRMS: THE LIMITS ON ATTORNEY EMPLOYMENT DISCRIMINATION CLAIMS AND THE PROSPECTS FOR CREATING HAPPY LAWYERS
}

Nancy Levit ${ }^{*}$

\section{HAPPY AND UNHAPPY LAWYERS}

Researchers say lawyers are about in the middle of the pack for job happiness when compared to members of many other professions. In a study by the National Opinion Research Center of almost two hundred occupations, lawyers ranked below clergy, firefighters, special education teachers, architects, engineers, scientists, housekeepers, repair people, and a host of other workers in terms of general happiness with their jobs. ${ }^{1}$ However, lawyers did rank their job satisfaction higher than construction laborers, press machine operators, roofers, and gas station attendants. $^{2}$

In one poll of American lawyers, $43 \%$ report that they are generally "very happy"3 — which is not in itself a disturbing statistic but one that does suggest that more than half of all lawyers are not among the very happy ones. More than four out of every ten lawyers responding to a recent American Bar Association survey

\footnotetext{
* Curators' and Edward D. Ellison Professor of Law, University of Missouri-Kansas City School of Law. My deepest thanks and gratitude go to Richard Bales, June Carbone, Ben Cooper, Barbara Glesner Fines, Peter Huang, Lawrence D. MacLachlan, Marcia McCormick, Allen Rostron, and Paul Secunda. Alex Edelman provided exceptional research assistance.

${ }^{1}$ Tom W. Smith, Job Satisfaction in the United States, NATIONAL OpINION RESEARCh CENTER AT THE UNIVERSITY OF CHICAGO (Apr. 17, 2007), http://www-news.uchicago.edu/releases/07/pdf/070417.jobs .pdf.

${ }^{2} I d$. at 3-6.

${ }^{3}$ Id. at 3; see also RONIT DinOvitZer ET AL., AFTER THE JD: FIRST RESUlts OF A NATIONAL STUDY OF LEGAL CAREERS (2004), available at http://www.americanbarfoundation.org/uploads/CMS/documents/ ajd.pdf.
} 
said that they would not recommend law as a career to young adults. ${ }^{4}$ Polls from the 1990s are far more cautionary, showing that between 60 and $70 \%$ of those responding would select a career other than law if they could make the decision over again. $^{5}$

Large law firms are losing a significant number of their newer lawyers - “a whopping 37 percent of associates at big law firms, defined by the study as those employing more than 500 lawyers, quit their firms by the end of their third years of practice." In the longitudinal After the JD study, 45\% of those working at 101-250 lawyer firms and $55 \%$ of those working at law firms with more than 250 lawyers either expected to or were actively planning to change jobs within the next two years. ${ }^{7}$ Female associates leave private practice at almost twice the rate of comparable male associates. ${ }^{8}$ Minority women, although satisfied with their choice of career, are leaving their jobs at large law firms at record rates. ${ }^{9}$ In $2005,81 \%$ of female associates of color changed jobs within five years. ${ }^{10}$ Other indicators of career dissatisfaction are the high rates of depression, alcoholism, and suicide among members of the profession. ${ }^{11}$

${ }^{4}$ Stephanie Francis Ward, Pulse of the Legal Profession: 800 Lawyers Reveal What They Think About Their Lives, Their Careers, and the State of the Profession, A.B.A. J., Oct. 2007, at 30, 32.

${ }^{5}$ John P. Heinz et al., Lawyers and Their Discontents: Findings from a Survey of the Chicago Bar, 74 IND. L.J. 735, 735-36 (1999); Fax Poll: It Becomes a Miserable Profession, CAL. LAW., Mar. 1992, at 96; Alex Williams, The Falling-Down Professions, N.Y. Times, Jan. 6, 2008, at ST1, 8-9.

${ }^{6}$ Ashby Jones, The Third-Year Dilemma: Why Firms Lose Associates, Wall St. J., Jan. 4, 2006, http://online.wsj.com/public/article/SB113571843977932357-8Y4J8IbL83hNYhzRvOlBaO5OtXM 20060111.html.

${ }^{7}$ DiNOVITZER ET AL., supra note 3, at 54 .

${ }^{8}$ ABA COMmission on WOMEN In the Profession, GoAl IX REPORT CARD: AN ANNUAL REPORT ON WOMEN's AdVANCEMENT INTO LEAdERShip Positions in the AMERICAN BAR AsSOCIATION 4 (Feb. 2008).

${ }^{9}$ See Wayne J. Lee, President's Message: Brown v. Board: Are We There Yet?, 51 LA. B.J. 404, 405 (Apr./May 2004); Charles Toutant, Women, Minorities Make Strides at Firms, But ABA Study Casts Pall: High Minority-Women Attrition Rate Pegged to Firms' Insensitivities, 185 N.J. L.J. 653, 657 (Aug. 21, 2006); Debra Cassens Weiss, Survey Reveals the Unhappiest Associates, A.B.A. J. (Nov. 7 , 2007, 6:45 AM), http://www.abajournal.com/news/survey_reveals_the_unhappiest_associates.

${ }^{10}$ See Toutant, supra note 9 , at 657.

${ }^{11}$ See G. Andrew H. Benjamin et al., The Prevalence of Depression, Alcohol Abuse, and Cocaine Abuse Among United States Lawyers, 13 INT'L J.L. \& PSYCHIATRY 233, 240 (1990), available at http://www.lawyerswithdepression.com/uploads/dep2.pdf; William W. Eaton et al., Occupations and the Prevalence of Major Depressive Disorder, 32 J. Occupational MED. 1079, 1083 (1990). 
It would be wrong, though, to think that most lawyers would be more likely to find satisfaction elsewhere. Lawyers are generally less happy than those in occupations that offer numerous opportunities for pleasurable social connections, such as hairdressers, ministers, and educators. ${ }^{12}$ They are generally more satisfied than those in isolating jobs or jobs that entail repetitive work, such as manual labor, or pressure-driven jobs that offer little in the way of intellectual stimulation, such as customer service work. ${ }^{13}$

More recent studies suggest that the earlier polls regarding lawyer career dissatisfactions may have drawn heavily on self-selected disgruntled respondents. ${ }^{14}$ A 2007 study of more than 9,000 lawyers in firms of varying sizes sampled from regions across the nation showed that almost $80 \%$ of respondents were satisfied with their decisions to become a lawyer. ${ }^{15}$ This measure tracks the responses of a twenty-year longitudinal study of the University of Virginia Law School class of 1987 , in which $81 \%$ of the respondents said they were "satisfied with their decision to become a lawyer, and $86 \%$ satisfied with their lives more broadly." 16 Eight out of ten lawyers answering an ABA survey were proud to be attorneys, and the same number found the practice of law to be intellectually stimulating. ${ }^{17}$

Even though the majority of lawyers are generally satisfied with their occupational choice, many are stressed by billable hour requirements and the pressures of keeping up a steady stream of clients and income. ${ }^{18}$ The least happy lawyers are those practicing in large law firms - only $44 \%$ of Biglaw lawyers report that they are satisfied. ${ }^{19}$

${ }^{12}$ Smith, supra note 1.

${ }^{13} I d$.

${ }^{14}$ See Kathleen E. Hull, Cross-Examining the Myth of Lawyers' Misery, 52 VAND. L. REv. 971, 972 (1999).

${ }^{15}$ Ronit Dinovitzer \& Bryant G. Garth, Lawyer Satisfaction in the Process of Structuring Legal Careers, 41 LAW \& SOC'Y REV. 1, 9 (2007) (noting that 35\% reported being "extremely satisfied," while $44 \%$ were "moderately satisfied").

${ }^{16}$ John Monahan \& Jeffrey Swanson, Lawyers at Mid-Career: A 20-Year Longitudinal Study of Job and Life Satisfaction, 6 J. EMPIRICAL LEGAL STUD. 451, 452 (2009).

${ }^{17}$ Ward, supra note 4, at 32-33.

${ }^{18} I d$. at 34 .

${ }^{19}$ Dinovitzer \& Garth, supra note 15 , at 7. 
Part of the unhappiness, particularly among women and lawyers of color, may relate to employment discrimination. ${ }^{20}$ The diversity statistics concerning partnership are ominous, particularly for lawyers of color and, to a lesser but still significant extent, white women. ${ }^{21}$ Even though females often constitute "half the entry class of associates at large law firms," many very quickly encounter glass ceilings, stereotypes about their abilities, limited mentoring, and "conservative workplace structures that are inhospitable to work-life concerns." ${ }^{.22}$ At major law firms, women comprise only $19 \%$ of all partners, ${ }^{23}$ less than $16 \%$ of equity partners, and only $6 \%$ of managing partners. ${ }^{24}$ Racial minorities represent only $5.4 \%$ of equity partners, ${ }^{25}$ and women of color are fewer than $2 \%$ of that group. ${ }^{26}$ Discrimination is a reasonable explanation for at least some lawyer misery; in practice, the discrimination often simply takes the form of actions based on subordinating stereotypes. ${ }^{27}$

${ }^{20}$ See generally Scott A. Moss \& Peter H. Huang, How the New Economics Can Improve Employment Discrimination Law, and How Economics Can Survive the Demise of the "Rational Actor," 51 WM. \& MARY L. REV. 183 (2009) (offering ways that behavioral research on happiness can be useful to courts, especially in assessing damages for discrimination against particular groups).

${ }^{21}$ Eli Wald, Glass Ceilings and Dead Ends: Professional Ideologies, Gender Stereotypes, and the Future of Women Lawyers at Large Law Firms, 78 FORDHAM L. REV. 2245, 2247 (2010).

${ }^{22} I d$. at 2246.

${ }^{23}$ Karen Sloan, Report Finds Slight Improvement in Firm Diversity, But Pockets of Decline, N.Y. L.J., Oct. 23, 2009, at 6 .

${ }^{24}$ Stephanie A. Scharf et al., Report of the Fourth Annual National Survey on Retention and Promotion of Women in Law Firms, NATIONAL ASSOCIATION OF WOMEN LAWYERS \& THE NAWL FOUNDATION, at 2 (Oct. 2009), http://nawl.timberlakepublishing.com/files/2009\%20Survey\%20Report\%20FINAL .pdf.

${ }^{25}$ Nicole Lancia, Note, New Rule, New York: A Bifocal Approach to Discipline and Discrimination, 22 GeO. J. LeGAL ETHICS 949, 960 (2009).

${ }^{26}$ Jessica Faye Carter, Leave None Behind, NAT'L L.J., Dec. 8, 2008, at 23 ("Minority women account for $1.88 \%$ of partners at major U.S. law firms."); Letter from Fernande R.V. Duffly et al. to Board of Directors National Association of Law Placement (Apr. 6, 2010), available at http://online.wsj.com/ public/resources/documents/NAWJletter.pdf (stating that females of color constitute $1.7 \%$ of managing partners); Law Firm Diversity Demographics Slow to Change-Minority Women Remain Particularly Scarce in Law Firm Partnership Ranks, THE Ass'N FOR LEGAL CAREER Prof'LS (Dec. 10, 2008), http://www.nalp.org/lawfirmdiversity ("At just $1.84 \%$ of partners, this group [minority women] is thus particularly underrepresented in the partnership ranks, even more so than minority men, who account for just $4.08 \%$ of partners.").

${ }^{27}$ See, e.g., Fiona M. Kay \& John Hagan, Cultivating Clients in the Competition for Partnership: Gender and the Organizational Restructuring of Law Firms in the 1990s, 33 LAW \& Soc'Y REV. 517, 521 (1999). 
Some lawyers are so unhappy with conditions, work assignments, or failures to secure promotions that they sue their firms for employment discrimination. ${ }^{28}$ Lawyers do not often sue their law firms because discrimination suits in this context are among the most difficult types of cases to bring and to win. ${ }^{29}$

This article evaluates the particular difficulties lawyers face, as a matter of both employment discrimination doctrine and practical politics, when they sue their firms. ${ }^{30}$ Part II explores the most common types of lawsuits by lawyers against law firms - causes of action for disparate treatment (often in the failure-to-promote context), disparate impact, sexual harassment, and retaliation-as well as the doctrinal impediments to these claims. This Part also considers the cultural limitations on suits by lawyers. Legal communities are often small and may be unforgiving if lawyer plaintiffs sue their own firms. Although the pragmatic problems remain, Part III explores several more promising avenues for legal redress of certain types of lawyer claims in the areas of family responsibilities, discrimination, and claims by partners against their partnerships. It also looks at possible claims under state discrimination statutes and state employment law theories, tort theories, and common law claims, including breach of fiduciary responsibilities and contract-based suits. While litigation has made some headway into the architecture of inequity in firms, happiness in law firm life is often unreachable through standard employment discrimination mechanisms. Many of the features of their working lives that make lawyers unhappy, things like excessive billable hour requirements or an absence of control over their dockets, are not working conditions that are appropriate subjects for lawsuits.

Part IV thus moves in a different direction. This section applies the new "science of happiness" research in the field of psychology to the lives of lawyers. It examines some self-help measures for lawyers who want to find greater happiness at work. This part also explores the practical and economic reasons why law firms should want to promote the happiness of their lawyers. Part V concludes that in many ways - although for different reasons - the interests of law firms and their lawyers are united. Studies show that law firms benefit economically when their lawyers are more satisfied with their working conditions. When lawyers work in

\footnotetext{
${ }^{28}$ See infra Part II.

${ }^{29} \mathrm{Id}$.

${ }^{30}$ Many of the issues discussed in this article apply to legal secretaries and other law firm staff, as well. An excellent treatment of the roles and working lives of legal secretaries is Felice Batlan, If You Become His Second Wife, You are a Fool': Shifting Paradigms of the Roles, Perceptions, and Working Conditions of Legal Secretaries in Large Law Firms, 52 STUD. L. POL. SOC’Y 169 (2010).
} 
firms that value their contributions and give them some autonomy, flexibility, feedback, and a sense of mattering, they like their work more and repay those human investments with increased productivity. Although the process of normative change in law firms is often glacially slow, turbulence in the economy, greater information transparency, and generational shifts that free workers from thinking they must make lifetime commitments to a single institution may herald welcome changes in law firm cultures.

\section{LAWSUITS BY LAWYERS}

Although Title VII helped women and minorities gain entry into law firms in the $1970 \mathrm{~s},{ }^{31}$ the cases thirty years later are not about flat-out refusals to hire, and statutory relief is unavailable much of the time-numerically, doctrinally, and pragmatically. First, approximately $70 \%$ of lawyers on the private side practice in firms with fewer than fifteen employees and are thus outside the reach of Title VII. ${ }^{32}$ However, state fair employment practice statutes may mirror Title VII protection and extend to employers with fewer than fifteen employees. ${ }^{33}$

In the pantheon of employment discrimination cases, lawsuits by lawyers against their firms are relatively rare, and suits by in-house counsel are almost nonexistent. ${ }^{34}$ Even when the suits exist and they are good ones, law firms often create employment contracts with their attorneys that require any suit against the firm to be submitted to arbitration. ${ }^{35}$ The federal appellate courts arrive at mixed

\footnotetext{
${ }^{31}$ See, e.g., Blank v. Sullivan \& Cromwell, 418 F. Supp. 1 (S.D.N.Y. 1975) (certifying a class suing a prominent law firm for sex discrimination); Kohn v. Royall, Koegel \& Wells, 59 F.R.D. 515 (S.D.N.Y. 1973) (certifying a class of past and future female applicants for a legal job with a law firm).

${ }^{32}$ See Anthony J. Luppino, Multidisciplinary Business Planning Firms: Expanding the Regulatory Tent Without Creating a Circus, 35 SetON HaLl L. Rev. 109, 160 n.187 (2004) (observing "that in 2000, $69.9 \%$ of U.S. lawyers in private practice were practicing solo or in firms of ten or less"); see also Sally E. Anderson, Special Considerations for Sole and Small Firm Practitioners, AM. BAR Ass'N, http://apps.americanbar.org/legalservices/lpl/downloads/soleandsmallfirm.pdf (last visited Aug. 30, 2010) ("nearly 80 percent of lawyers in the United States currently practice in firms of this size [one to five lawyers]").

${ }^{33}$ See, e.g., DEL. CODE ANN. tit. 19, § 710(6) (2008) (employer must have at least four employees); Mo. REV. STAT. § 213.010(7) (2008) (employer must have at least six employees); N.Y. EXEC. LAW $\S 292(5)$ (McKinney 2007) (employer must have at least four employees); 43 PA. CONS. STAT. § 954(b) (2008) (employer must have at least four employees); VA. CODE ANN. § 2.2-2639 (2008) (employer must have at least six employees).

${ }^{34}$ Sue Reisinger, Sued by One of Its Own: A Top In-House Lawyer at GE Accuses the Company of Gender Bias, Miami Daily Bus. Rev., Aug. 16, 2007, at 9.

${ }^{35}$ See, e.g., Brown v. Dorsey \& Whitney, LLP, 267 F. Supp. 2d 61, 83 (D.D.C. 2003); see also Douglas R. Richmond, The Partnership Paradigm and Law Firm Non-equity Partners, 58 U. KAN. L. REV. 507,
} 
results on arbitration clauses, with a number of courts upholding agreements to arbitrate, ${ }^{36}$ and a few courts finding reasons - such as a partner-shareholder never being provided with the bylaws - to refuse to enforce compulsory arbitration clauses in claims against the partnership. ${ }^{37}$ There is also good anecdotal evidence that potential lawsuits against firms are resolved nonpublicly through negotiated settlements. ${ }^{38} \mathrm{We}^{\text {'re lawyers - we invented confidentiality agreements. }}{ }^{39}$

The early Title VII cases pursued by lawyers against their firms were hiring cases, ${ }^{40}$ but there are fewer hiring lawsuits in the modern era and more claims regarding denial of partnership. ${ }^{41}$ The most common types of employment discrimination suits by lawyers against firms are for disparate treatment and harassment, with retaliation claims thrown in for good measure. Although disparate impact suits would seem to be statistically promising, the proof problems are

537 (2010) (“" $[\mathrm{M}]$ any law firm partnership agreements include arbitration provisions, meaning that deequitization disputes are contested privately.”).

${ }^{36}$ See, e.g., Panepucci v. Honigman Miller Schwartz \& Cohn LLP, 281 Fed. App'x 482, 483 (6th Cir. 2008); Brown v. Dorsey \& Whitney, LLP, 267 F. Supp. 2d 61, 83 (D.D.C. 2003); Williams v. Katten, Muchin \& Zavis, 837 F. Supp. 1430, 1431 (N.D. Ill. 1993).

${ }^{37}$ See, e.g., Kirleis v. Dickie, McCamey \& Chilcote, P.C., 560 F.3d 156 (3d Cir. 2009).

${ }^{38}$ Michael Ann Knotts, Putting Up with Gender Bias or Suing: Female Attorneys Go for Broke, 12 N.J. LAW. 1801 (2003). Numerous cases that make a splash in the news simply go away. Some may be settled; some may be without foundation (and some may be both) - it is just not possible to tell from the public record. See, for instance, the news reports of a black female associate who sued the Belgium office of the prominent Howrey law firm for race discrimination, seeking damages of $\$ 30$ million. Jeff Jeffrey, Howrey Slapped with \$30 Million Racial Discrimination Suit, LAW.COM (Jan. 28, 2010), http://www.law.com/jsp/article.jsp?id=1202439559651. The suit was quietly dismissed three months later. Menns v. Howrey LLP, 2010 CA 000434 B. Similarly, Sullivan \& Cromwell settled a lawsuit against the firm by one of its associates for anti-gay discrimination and retaliation. The terms of the settlement were, unsurprisingly, confidential. David Lat, Breaking: Sullivan \& Cromwell Settles With Aaron Charney!!!, ABOve THE LAw (Oct. 26, 2007, 12:30 AM), http://abovethelaw.com/2007/10/ breaking-sullivan-cromwell-settles-with-aaron-charney/. See Complaint, Aaron Brett Charney v. Sullivan \& Cromwell, No. 06-07100625 (N.Y. Sup. Ct. Jan. 16, 2007) (Findlaw), available at news.findlaw.com/hdocs/docs/glrts/charneysc11607cmp.pdf; David Lat, Charney v. Sullivan \& Cromwell: Does S\&C Hate Gays (and Canadians)?, Above THE LAW (Jan. 16, 2007, 1:09 PM), http://abovethelaw.com/2007/01/charney-v--sullivan-cromwell-does-sc-hate-gays-and-canadians/.

${ }^{39}$ See, e.g., Brenda Sapino Jeffreys, Former Associate Settles Suit Against V and E, TEX. LAW., Jan. 24, 2005, at 1; Richmond, supra note 35, at 537. Plaintiffs may also appreciate the leverage that confidential settlements can bring. See, e.g., Knotts, supra note 38, at 1801 ("Attorneys who handle complaints by lawyers against their firms and employers said behind-the-scenes talks often are the most productive.").

${ }^{40}$ See, e.g., Cynthia Grant Bowman, Women in the Legal Profession from the 1920s to the 1970s: What Can We Learn from Their Experience About Law and Social Change?, 61 ME. L. REv. 1, 21 (2009).

${ }^{41}$ Cf. Knotts, supra note 38, at 1801. 
U N I V E R S I T Y OF P I T T S B U R G H L A W R E V I E W

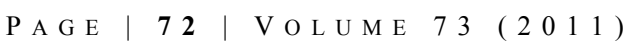

legion. The sections that follow describe the architecture of the more traditional types of employment discrimination suits filed against law firms.

\section{A. Difficulties With Disparate Treatment}

Lawyers suing law firms for disparate treatment often face insurmountable proof problems. The first is simply the problem of obtaining documentation. Since the defendants are law firms, evidentiary requests may face attorney-client and work-product privilege objections and carefully contoured discovery rulings. ${ }^{42}$ The broader problem is the difficulty of finding comparator evidence to establish differential treatment.

\section{The Absence of Comparator Evidence}

Since most suits by lawyers against their firms involve the internal workings of firms, the plaintiff usually lacks specific comparator evidence. ${ }^{43}$ For example, in Bilow v. Much Shelist Freed Denenberg Ament \& Rubenstein, P.C., ${ }^{44}$ a female attorney who sued her firm for failing to provide adequate staffing on her cases was unable to find similar cases in which male attorneys had received better staffing. ${ }^{45}$ The court found that the cases she identified for comparison "on which male attorneys seemingly received more assistance were cases that were either more complex, or were not contingent fee cases, or took place in Chicago and therefore did not entail the same travel expenses. ${ }^{, 46}$ In Byrd $v$. Ronayne, ${ }^{47}$ although the law firm had never considered any female associate for partnership before terminating the plaintiff, the court found that the plaintiff was unable to find an apt comparator because she had "not shown that any other associate - male or female - who failed to conform with the firm's professional standards, had ever been considered for partnership. ${ }^{, 48}$ Perhaps the plaintiff is a lateral, or in the bankruptcy department, or someone who has moved from real estate to bankruptcy. ${ }^{49}$ Or the female plaintiff

\footnotetext{
${ }^{42}$ See, e.g., Tumbling v. Merced Irr. Dist., 262 F.R.D. 509 (E.D. Cal. 2009).

${ }^{43}$ See, e.g., Mungin v. Katten Muchin \& Zavis, 116 F.3d 1549, 1555 (D.C. Cir. 1997); Clark v. Illinois Human Rights Comm'n, 728 N.E.2d 582, 588 (Ill. App. Ct. 2000).

${ }^{44} 277$ F.3d 882 (7th Cir. 2001).

${ }^{45} I d$. at 894 .

${ }^{46} I d$.

${ }^{47} 61$ F.3d 1026 (1st Cir. 1995).

${ }^{48} I d$. at 1032 n.7.

${ }^{49}$ See Mungin, 116 F.3d at 1555-56; Oshiver v. Levin, Fishbein, Sedran and Berman, 818 F. Supp. 104 (E.D. Pa. 1993).
} 
who is a document reviewer is unable to show any disparate treatment because the law firm has no males doing document review. ${ }^{50}$ The plaintiff may be someone who has performance issues..$^{51}$ In short, most law practice is so individualized that comparator evidence simply does not exist. Even if the plaintiff can demonstrate that she was essentially replaced when her job responsibilities were absorbed by other lawyers, this evidence is difficult to amass. ${ }^{52}$ The absence of an individual comparator can be fatal to the plaintiff's case. ${ }^{53}$

Dow v. Donovan, ${ }^{54}$ from the U.S. District Court for the District of Massachusetts, is an unusual case in which the trial court did not require the female plaintiff who was passed over for partnership to find a similarly situated male comparator. ${ }^{55}$ Instead, the court stated that the plaintiff's burden under pretext analysis at the summary judgment stage was "simply [to] show that after her dismissal, the partnership "had a continued need for someone to perform the same work. " 56 The court also considered the inconsistencies between notes the partners made about the plaintiff's mixed strengths and weaknesses during her eight years on the partnership track and the vitriolic attack affidavits submitted by the partners in opposition to Dow's lawsuit as evidence of pretext: “The partners' wholesale attack on Dow's legal abilities, intelligence and even personality is patently incredible. ${ }^{.57}$

One court was willing to engage in comparator analysis in the promotion context even when the attorneys were doing different kinds of work-but the surrounding facts were outstandingly bad. In Masterson v. LaBrum \& Doak, the federal district court held that a female attorney who was rejected for partnership

${ }^{50}$ Ullmann v. Olwine, Connelly, Chase, O’Donnell \& Weyher, 123 F.R.D. 237, 247 (S.D. Ohio 1987).

${ }^{51}$ See Fox v. Giaccia, 424 F. Supp. 2d 1, 8 (D.D.C. 2006) (granting summary judgment on disparate treatment claims based on documented performance declines by a word processor employed by a law firm and noting the absence of a comparator with similar performance issues).

${ }^{52}$ See Spera v. Kosieradzki Smith Law Firm, LLC, No. A09-1907, 2010 WL 2650540, at*3 n.1 (Minn. Ct. App. July 6, 2010).

${ }^{53}$ See, e.g., Puckett v. McPhillips Shimbaum, No. 2:06-CV-1148-ID, 2010 WL 1729104, at *3-4 (M.D. Ala. Mar. 30, 2010) (recommending that the district court grant summary judgment on paralegal plaintiff's age discrimination claim against his law firm, in part because of the absence of comparator evidence).

${ }^{54} 150$ F. Supp. 2d 249 (D. Mass. 2001).

${ }^{55}$ Id. at 262.

${ }^{56}$ Id. (quoting Cumpiano v. Banco Santander Puerto Rico, 902 F.2d 148, 155 (1st Cir. 1990)).

${ }^{57}$ Id. at 257. 
had established a prima facie case. ${ }^{58}$ The court looked at the criteria for partnership that the law firm applied to a slate of candidates-billings, receipts, and assessments of legal skills — and found that while male candidates had been told that client development was "a necessary criterion for partnership," the plaintiff had not. ${ }^{59}$ Also important to the Masterson court was the partners' lack of conducting even-handed evaluations, their neglecting to inform the plaintiff that client development would be important to the partnership determination, and their failure to give credit to Ms. Masterson's prior judicial clerkship, the jury trials she had done, and the business she had developed. ${ }^{60}$ Masterson, though, is a fairly extreme case in which the firm's historical treatment of women factored into the court's decision. ${ }^{61}$ It is also one that is almost two decades old.

Many contemporary cases outside the law firm context find that proposed comparators are not valid because of minor variations in job responsibilities or conduct. ${ }^{62}$ Indeed, the exacting standard in a number of circuits is that comparators need to be "similarly situated in all relevant respects" and "nearly identical to the plaintiff." 63 This limited view of suitable comparator evidence means that cases will fail for want of appropriate comparators. ${ }^{64}$

\section{Subtle Stereotypes and Unconscious Discrimination}

After Desert Palace, Inc. v. Costa, ${ }^{65}$ direct evidence of discriminatory intent is not required. ${ }^{66}$ Of course, it rarely exists anyway. It is also difficult to compile

${ }^{58} 846$ F. Supp. 1224, 1227, 1232 (E.D. Pa. 1993).

${ }^{59} I d$. at 1229.

${ }^{60}$ Id. at $1229-30$.

${ }^{61}$ See, e.g., Audrey Wolfson Latourette, Sex Discrimination in the Legal Profession: Historical and Contemporary Perspectives, 39 VAL. U. L. REV. 859, 889 (2005) (reading Masterson as "suggest[ing] that in order to prevail in a sex discrimination case, one must present rather compelling evidence of patently unfair behavior and distinct differences in the treatment of males and females, with historical discriminatory policies toward women providing supporting evidence of an employer's discriminatory intent").

${ }^{62}$ See Charles A. Sullivan, The Phoenix From the Ash: Proving Discrimination by Comparators, 60 ALA. L. REV. 191, 213-23 (2009).

${ }^{63}$ See, e.g., Hill v. Emory Univ., 346 Fed. App'x 390, 395 (11th Cir. 2009); Wilson v. B/E Aerospace, Inc., 376 F.3d 1079, 1091 (11th Cir. 2004); see also Perez v. Tex. Dep't of Criminal Justice, 395 F.3d 206, 213 (5th Cir. 2004) (requiring that “the comparator employees' circumstances and misconduct be 'nearly identical' to that of the plaintiff-employee" (quoting Wallace v. Methodist Hosp. Sys., 271 F.3d 212 (5th Cir. 2001))).

${ }^{64}$ See Sullivan, supra note 62, at 213-23.

${ }^{65} 539$ U.S. 90 (2003). 
circumstantial evidence that discrimination was a motivating factor in employment decisions regarding attorney-employees. ${ }^{67}$ The defendants, after all, are lawyers.

Since almost all lawyers took constitutional law in law school, they should know better than to make explicit references to protected identity categories. From Price Waterhouse v. Hopkins, ${ }^{68}$ they learned not to put things in the file like "too "macho" and "in need of "charm school." ${ }^{69}$ Lawyers know how to speak in code words, shrugs, nods, and eye-rolls that are not reflected "on the record." Even outside of the lawyer-versus-law-firm context, the use of coded language to facilitate discrimination is all too common. ${ }^{70}$ For example, the Second Circuit held that a refusal to rehire a 58 year-old production manager on the basis that he was "overqualified" could establish discriminatory animus regarding his age: "For those individuals in the protected age group, such a reason may often be simply a code word for too old." ${ }^{, 71}$ In another case, where white supervisors subjected black employees to disproportionately harsh discipline, insulted them by cautioning them not to steal anything, and referred to black employees as "another one," "one of them," or "all of you," the court held that "the use of "code words," when coupled with the circumstantial treatment of the plaintiffs, could amount to a Title VII violation. $^{72}$

In the rare case, a plaintiff may be able to assemble pieces of circumstantial evidence that paint a "convincing mosaic" showing discriminatory treatment. ${ }^{73}$ One such case was Hasan v. Foley \& Lardner LLP, where a Muslim lawyer alleged discriminatory treatment following the September 11 terrorist attack, and the plaintiff was able to obtain testimony about explicit anti-Muslim statements (one partner reported to the plaintiff that during the termination discussion other partners participated in a "sand-nigger pile-on" and "took out their religious dispute in Israel

${ }^{66} I d$. at 92.

${ }^{67}$ See, e.g., Price Waterhouse v. Hopkins, 490 U.S. 228 (1989).

${ }^{68} I d$.

${ }^{69}$ Id. at 235.

${ }^{70}$ See, e.g., Michael OMi \& Howard Winant, Racial Formation In the United STATES: From THE 1960 S TO THE 1980 s, at 123 (2d ed. 1994).

${ }^{71}$ Taggart v. Time Inc., 924 F.2d 43, 44 (2d Cir. 1991).

${ }^{72}$ Aman v. Cort Furniture Rental Corp., 85 F.3d 1074, 1082-83 (3d Cir. 1996).

${ }^{73}$ Hasan v. Foley \& Lardner LLP, 552 F.3d 520, 526 (7th Cir. 2008) (quoting Hassan v. Foley \& Lardner, LLP, 2007 LEXIS 54930 (N.D. Ill. 2007), overruled by Hassan, 552 F.3d 520). 
U N I V E R S I T Y OF P I T T S B U R G H L A W R E V I E W

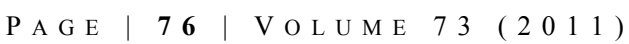

on you and had you fired"). ${ }^{74}$ The plaintiff coupled this evidence with other facts about the suspicious timing of the partners' change in attitude toward him relative to September 11, internal memoranda that the firm had plenty of work, his positive performance evaluations, and a partner's efforts to get another partner to retract a positive evaluation of the plaintiff. ${ }^{75}$ The cumulative circumstantial picture created a jury question.

On the other hand, numerous courts demonstrate a lack of sensitivity to possible coded language and refuse to even let juries decide factual implications. In Mayer v. Nextel West Corp., a newly hired 34-year-old general manager gave the directive to hire the "right" people, which he defined as "those with two to six years ... experience," and fired a 60-year-old sales manager without explanation. ${ }^{76}$ The court held that these words did not create even a jury question of age-based animus. ${ }^{77}$ Similarly, courts have held that saying a female dispatcher lacked the "confrontational skills" to manage truck drivers ${ }^{78}$ or commenting that a male teacher was "too macho" were not gendered comments. ${ }^{79}$ In one lawyer-versuslaw-firm case, a partner allegedly said to a female attorney, "[I]f you were my wife, I would not want you working after having children[.]" ${ }^{\prime 80}$ The court decided that this comment did not rise to the level of direct evidence in the terminated female attorney's Pregnancy Discrimination Act suit because the partner who made the comment, although the plaintiff's direct supervisor, "did not speak significantly about plaintiff at the meeting regarding her termination and also abstained from the vote to terminate her." 81

Courts may even minimize the importance of specific evidence of clearly gendered language. For instance, in an older case involving a senior associate's sex discrimination claim against her law firm, Neuren v. Adduci, Mastriani, Meeks \& Schill, the plaintiff sued because the firm terminated her. ${ }^{82}$ The firm defended that

\footnotetext{
${ }^{74} I d$. at 524 .

${ }^{75} \mathrm{Id}$. at $528-31$.

${ }^{76}$ Mayer v. Nextel West Corp., 318 F.3d 803, 805 (8th Cir. 2003).

${ }^{77}$ Id. at $808-09$.

${ }^{78}$ Crone v. United Parcel Serv., 301 F.3d 942 (8th Cir. 2002).

${ }^{79}$ Lautermilch v. Findlay City Sch., 314 F.3d 271 (6th Cir. 2003).

${ }^{80}$ Kennedy v. Schoenberg, Fisher \& Newman, Ltd., 140 F.3d 716 (7th Cir. 1998).

${ }^{81} I d$. at 724 .

8243 F.3d 1507 (D.C. Cir. 1995).
} 
the plaintiff had trouble meeting deadlines and lacked interpersonal skills. She submitted evidence of a partner's written evaluation that stated she was "[e]xtremely difficult on secretarial and support staff. A bitch!" 83 The D.C. Circuit Court of Appeals acknowledged that "this pejorative term may support an inference that an employment decision is discriminatory under different circumstances," yet held that in the context of the plaintiff's evaluation, it was simply a "crude word choice" and was "grounded in gender-neutral concerns about Neuren's interpersonal relations with co-workers, rather than discriminatory considerations." 84

The difficulty of establishing that unconscious forms of stereotyping constitute discrimination is amplified in the law firm context. Subtle forms of exclusion are rampant within law firms but, in most cases, are hard to document. ${ }^{85}$ It is difficult to tie perceptions about differential treatment to evidence of it. ${ }^{86}$ Proof problems accompany the operation of an internal labor market. The channels for workflow are often chaotic. The sharing of information, selection for case assignments, grooming, lunches, and golf that are important to career advancement are often the product of informal mentoring networks. ${ }^{87}$ It is difficult to trace these more subtle forms of bias, subjective evaluation mechanisms, and exclusions from networking opportunities. As Susan Sturm explains: "Those involved in conduct producing bias may not perceive their behavior as problematic or discriminatory. ... Under some circumstances, the boundaries between legitimate and illegitimate behavior will be quite difficult to draw." 88

${ }^{83} I d$. at 1510 .

${ }^{84} I d$. at 1513 .

${ }^{85}$ See John Hagan \& Fiona Kay, Gender In PRACTice 161-62 (1995).

${ }^{86}$ See, e.g., King v. Phelps Dunbar, L.L.P., 844 So. 2d 1012 (La. Ct. App. 2003) (rejecting black associate's claim of race discrimination against his law firm when the associate worked fewer hours than other associates and offered primarily his own subjective opinion testimony that work assignments and other treatment were based on his race); Dziamba v. Warner \& Stackpole LLP, 778 N.E.2d 927, 932 (Mass. App. Ct. 2002) (deciding that the plaintiff's belief that he was discharged because of his depression was unfounded and termination was based instead on the partners' "perception that he lacked the ability to handle cases efficiently and to inspire the confidence of clients").

87 See Jennifer L. Pierce, Gender Trials 103-13 (1995); Ramona L. Paetzold \& Rafael Gely, Through the Looking Glass: Can Title VII Help Women and Minorities Shatter the Glass Ceiling?, 31 Hous. L. REV. 1517, 1533 (1995).

${ }^{88}$ Susan Sturm, Second Generation Employment Discrimination: A Structural Approach, 101 Colum. L. REV. 458, 468-69, 472 (2001). 
U N I V E R S I T Y OF P I T T S B U R G H L A W R E V I E W

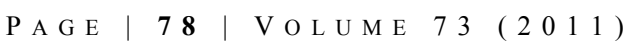

The informality and flux at law firms can also allow unconscious stereotypes to flourish. Informal processes - channels of communication, avenues of work assignments, access to influence - tend to allow preconceived biases to operate. ${ }^{89}$ In the absence of concrete measures for the assessment of capabilities or specific criteria for work assignments, stereotypes tend to fill the void. ${ }^{90}$ One commentator notes, for example, that "[w]omen are not stigmatized by overt beliefs that they should not be partners, or that they do not deserve the same salaries. Instead, their difficulties are anchored in assumptions about what it means to be a woman lawyer." ${ }^{" 11}$ Female and minority lawyers may not be viewed as the ideal workers. Suppositions that racial minorities are intellectually inferior or that "women place family responsibilities above professional commitments" and minorities are not tapped for plum assignments, are denied mentoring opportunities, or are slightly downgraded on evaluations. ${ }^{93}$ It is the subconscious stereotyping that is so difficult to eradicate and so difficult to document as the basis for legal redress. ${ }^{94}$

In Ezold v. Wolf, Block, Schorr \& Solis-Cohen, the Eastern District of Pennsylvania evaluated a law firm's denial of partnership to a female associate. ${ }^{95}$ She had received similar or better evaluations than male peers, but she had voiced concerns about "women's issues," such as the treatment of female lawyers and paralegals, and thus some partners thought she was "institutionally disloyal." ${ }^{96}$ She was also criticized for being demanding and too assertive, yet several male associates who had received criticism for their lack of assertiveness were promoted

${ }^{89}$ See, e.g., Richard Delgado et al., Fairness and Formality: Minimizing the Risk of Prejudice in Alternative Dispute Resolution, 1985 WIS. L. REV. 1359, 1387-89.

${ }^{90}$ Emily Calhoun, Workplace Discrimination: Truthfulness and the Moral Imagination, 16 VT. L. REV. 137 (1991).

${ }^{91}$ Christen Linke Young, Note, Childbearing, Childrearing, and Title VII: Parental Leave Policies at Large American Law Firms, 118 YALE L.J. 1182, 1200 (2009).

${ }^{92}$ David B. Wilkins \& G. Mitu Gulati, Why Are There So Few Black Lawyers in Corporate Law Firms? An Institutional Analysis, 84 CALIF. L. REV. 493, 557-58 (1996).

${ }^{93}$ Elizabeth Chambliss, Organizational Determinants of Law Firm Integration, 46 AM. U. L. REv. 669 , 691-92 (1997); Cynthia Fuchs Epstein et al., Glass Ceilings and Open Doors: Women's Advancement in the Legal Profession, 64 FordHAM L. REV. 291, 365 (1995); Deborah L. Rhode, The Subtle Side of Sexism, 16 COLUM. J. GeNDER \& L. 613, 617-26 (2007).

${ }^{94}$ Deborah L. Rhode, Speaking of SeX: The Denial of Gender InEQuality 145 (1997).

95751 F. Supp. 1175 (E.D. Pa. 1990), rev'd, 983 F.2d 509 (3d Cir. 1992).

${ }^{96}$ Id. at 1178 . 
to partner. ${ }^{97}$ The district court found that the differential treatment was based on sex and violated Title VII. The Third Circuit reversed and replaced the trial court's factfinding with its own, saying that although there was no evidence that Ezold "was not a good courtroom lawyer, dedicated to her practice, and good with clients," it believed the law firm's justification that Ezold lacked the analytic ability to be a partner. ${ }^{98}$ Missing the irony of its own actions, the Third Circuit also stated that courts should be cautious about "'unwarranted invasion or intrusion' into matters involving professional judgments about an employee's qualifications for promotion within a profession." 99

Even if attorneys are able to establish a prima facie disparate treatment case, it is not at all difficult for defendant firms to come up with legitimate nondiscriminatory reasons for treating each lawyer individually. Courts offer firms wide latitude on reasons for discharge, such as a firm's need to cut costs or promote rainmakers, lack of sufficient work to occupy a lawyer, ${ }^{100}$ or simply dissatisfaction with work performance. ${ }^{101}$ In sum, disparate treatment suits pose significant proof problems. Systemic disparate treatment and disparate impact cases are even more problematic.

\section{B. Difficulties With Disparate Impact and Systemic Disparate Treatment}

\section{Disparate Impact}

Plaintiffs may be able to make the best statistical case for a bottom-line discrepancy in promotional and advancement opportunities, given stark disparities

\footnotetext{
${ }^{97}$ Id. at 1192 .

${ }^{98}$ Ezold v. Wolf, Block, Schorr \& Solis-Cohen, 983 F.2d 509, 526 (3d Cir. 1992).

${ }^{99}$ Id. at 527.

${ }^{100}$ Given the current recession, law firms can probably justify many personnel decisions by pointing to the economy. See, e.g., Bilow, 277 F.3d at 894 (referring to the firm's need to cut costs and cut back on staffing as legitimate nondiscriminatory reasons); Wanamaker v. Columbian Rope Co., 907 F. Supp. 522 (N.D.N.Y. 1995) (downsizing and elimination of in-house counsel position was a legitimate nondiscriminatory reason for the corporation's action in terminating lawyer).

${ }^{101}$ Kelly v. Moser, Patterson \& Sheridan, LLP, 348 Fed. App’x 746 (3d Cir. 2009) (approving the lower court's grant of summary judgment to the defendant law firm in an age discrimination suit based on the plaintiff's failure to meet the firm's billable hours target, client complaints about the quality of the lawyer's work, and his rudeness to other lawyers and staff); Dorfman v. Doar Commc'ns, Inc., No. 03CV573SLTWDW, $2005 \mathrm{WL} 1861813$, at *5 (E.D.N.Y. 2005) (finding that the law firm offered legitimate reasons for termination of the 59 year old lawyer plaintiff, including "his failure to generate revenue as Senior Case Director and his inability to complete the electronic briefs without management intervention").
} 
between the percentages of associates and partners based on race or sex. Although women represent almost half of all law school graduates and $31 \%$ of all lawyers, they only constitute $19 \%$ of all law firm partners. ${ }^{102}$ Racial minorities (African Americans, Hispanics, Asian Americans, and Native Americans, collectively) constitute slightly less than $10 \%$ of all lawyers in this country, ${ }^{103}$ yet only about $6 \%$ of law firm partners. ${ }^{104}$

Unfortunately, these collective statistics do not make a distinction between tiers of partners (such as equity and nonequity). The statistical case is also particularly difficult in the law firm context because the pool of comparable candidates for promotion varies within practice areas, according to roles, and with workflow and job performance. Comparative analysis of attorneys' jobs is difficult because the individual experiences, assignments, clients, and issues differ so dramatically. ${ }^{105}$

Lawyers can probably also make a decent case from social science evidence that "opportunistic behavior" is not blind to race or gender or other identity categories. ${ }^{106}$ This sort of supplementary expert testimony is sometimes admissible in disparate impact cases. ${ }^{107}$

These pieces of evidence about industry-wide, bottom-line statistics and general evidence about unconscious discrimination will not be enough to make a prima facie case. Under the strict rubrics of disparate impact law, most lawyers will find it difficult to make the statistical case that an individual law firm's employment practices had a disparate impact on them. A disparate impact case

102 American Bar Association's Commission on Women in the Profession, Goal III Report Card, AN AnN. RePORT On Women's AdVANCEMENT InTO LEADERSHIP POSITIONS IN THE A.B.A. 4 (Feb. 2010); Sloan, supra note 23, at 6; Andrew Bruck \& Andrew Canter, Note, Supply, Demand, and the Changing Economics of Large Law Firms, 60 STAN. L. REV. 2087, 2103 (2008).

${ }^{103}$ Eric Swedlund, Choose Law! Event Targets Would-be Lawyers, ARIZ. DAILY STAR, Mar. 3, 2007, at B5 (noting that 3.9\% are African American, 3.3\% are Hispanic, 2.3\% are Asian American, and $0.2 \%$ are Native American).

104 See National Association of Legal Career Professionals, Women and Minorities in Law Firms by Race and Ethnicity, NALP BuLL., Jan. 2010, available at http://www.nalp.org/race_ethn_jan2010.

105 See, e.g., U.S. Dep't of Labor, Bureau of Labor Statistics, OcCuPATIONAL OUTLOOK HANDBOOK, 2010-2011 Ed., http://www.bls.gov/oco/ocos053.htm \#nature (describing in detail the nature of the work performed by lawyers in various areas of specialization).

${ }^{106}$ Paetzold \& Gely, supra note 87 , at 1524 .

${ }^{107}$ See, e.g., Pietras v. Board of Fire Commrs., 180 F.3d 468, 475 (2d Cir. 1999), cert. denied, 528 U.S. 948 (1999). 
requires the plaintiff to demonstrate that a neutral employment practice of a particular employer caused a statistically significant adverse impact on a protected group. ${ }^{108}$ Bottom-line statistics regarding the outcome of a hiring or promotion process - even within a single employer's workplace - are insufficient. ${ }^{109}$ Plaintiffs are required to identify particular practices at each discrete step of the process that create the statistical imbalance. ${ }^{110}$

Identifying a specific, facially neutral employment practice that has a disparate impact by race or sex may be impossible in a law firm setting: lawyers work in varying practice areas and on numerous different cases, with myriad project assignments, and in constantly fluctuating teams. There are extraordinarily few disparate impact cases filed by lawyers against their firms. ${ }^{111}$ Successful outcomes in disparate impact claims are hard to find. ${ }^{112}$ In a recent suit, Young $v$. Covington \& Burling, a black staff attorney alleged that a law firm assigned a disproportionate number of blacks to staff attorney positions and then created a policy that prohibited the promotion of all staff attorneys, which resulted in black attorneys being "7.5 times more likely [than whites]" to be subject to nonpromotion. ${ }^{113}$ The district court allowed the disparate impact claim regarding the firm's job assignment policy to go forward.

Perhaps if the large law firm is as large as brokerage giant Smith Barney, the plaintiffs can find sufficient statistical evidence to show discriminatory patterns of work assignment. ${ }^{114}$ But even if the law firm is a larger one, it may not have a

\footnotetext{
${ }^{108}$ This is established through the two-standard-deviations analysis from Hazelwood School District $v$. United States, 433 U.S. 299, 308-09 n.14 (1977), and Castaneda v. Partida, 430 U.S. 482, 496-97 n.17 (1977), or by the Equal Employment Opportunity Commission's (EEOC) four-fifths, or $80 \%$ rule, which says that if a particular group is selected at less than $80 \%$ of the group with the highest selection rate, this creates a prima facie disparate impact case. EEOC Uniform Guidelines on Employee Selection Procedures, 29 C.F.R. $§ 1607.4(D)$ (1978).

${ }^{109}$ Connecticut v. Teal, 457 U.S. 440 (1982).

${ }^{110} I d$. at 441 .

${ }^{111}$ See, e.g., Young v. Covington \& Burling, LLP, 689 F. Supp. 2d 69 (D.D.C. 2010) (finding that the plaintiff's administrative complaint sufficiently raised a disparate impact claim regarding a law firm's job assignment and nonpromotion practices to satisfy administrative exhaustion requirements).

112 See Eunice Chwenyen Peters, Note, Making It to the Brochure But Not to Partnership, 45 WASHBURN L.J. 625, 642 n.157 (2006).

${ }^{113}$ Young v. Covington \& Burling LLP, 736 F. Supp. 2d 151, 155 (D.D.C. 2010).

${ }^{114}$ See Smith Barney Settles Sex Discrimination Suit, S.F. Chron., Aug. 14, 2008 at B-2 (reporting on $\$ 33$ million settlement by Smith Barney in response to allegations that "branch managers assigned most new clients to male brokers," who earned "hundreds of thousands of dollars in commissions").
} 
sufficient number of lawyers for a meaningful statistical comparison. ${ }^{115}$ Regarding most other firms, since approximately three-quarters of all lawyers work in firms with ten or fewer lawyers, even if support staff are added in to reach the Title VII employee threshold, there will almost certainly be an insufficient number of attorneys in comparable jobs for a disparate impact case. ${ }^{116}$

Obtaining a sufficient sample size to make a statistical case, even if it is one bolstered with expert testimony, ${ }^{117}$ may be impossible. Plaintiffs need to be similarly situated to their comparators in "all material respects." ${ }^{, 118}$ Large disparities may be required to show statistically significant disparate impacts when the sample sizes are small. ${ }^{119}$ Too small a sample size of comparable lawyers will not allow statistically valid inferences. ${ }^{120}$ If sound standard deviation analysis requires a pool of, perhaps, thirty comparable workers, ${ }^{121}$ it is unlikely that such a group exists anywhere except, perhaps, the practice areas of the largest law firms.

${ }^{115}$ A November 2010 online search of Martindale-Hubble showed the following results:

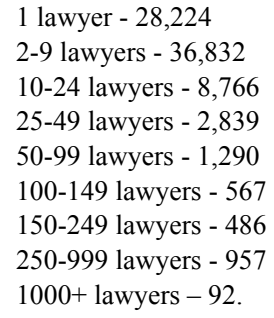

In short, lawyers in more than $80 \%(65,056$ of the 80,053$)$ of all law firms work in firms of fewer than ten lawyers. http://www.martindale.com/.

${ }^{116}$ See Luppino, supra note 32, at 160 n. 187.

${ }^{117}$ See Pietras, 180 F.3d at 475.

${ }^{118}$ Moran v. Selig, 447 F.3d 748, 755 (9th Cir. 2006). See also Wallace v. Skadden, Arps, Slate, Meagher \& Flom LLP, 799 A.2d 381, 386 (D.C. 2002) ("To sustain her burden, Dr. Wallace must show that she was treated differently from a Skadden employee, all of whose relevant employment aspects were 'nearly identical' to hers.").

${ }^{119}$ Jennifer L. Peresie, Toward a Coherent Test for Disparate Impact Discrimination, 84 IND. L.J. 773, 787 (2009).

${ }^{120}$ See, e.g., Knadler v. Furth, 253 F. App’x 661, 664 (9th Cir. 2007) (noting that although "there were no other Asian-American attorneys among the fifteen or so attorneys at the Furth Firm, we agree with the district court that this has little predictive value ... statistical evidence derived from an extremely small universe has little predictive value and must be disregarded").

${ }^{121}$ See, e.g., Conley v. U.S. Bank Nat. Ass'n, 211 F. App'x 402, 407 (6th Cir. 2006) (holding that the pool of ten managers was too small for disparate treatment calculations); Williams v. Tyco Elec. Corp., 161 F. App'x 526, 535 (6th Cir. 2006) (finding that a department of twenty offered too small a group for 
Even if the elements of a firm's decisional process are not capable of separation for analysis and the plaintiff is permitted to show a bottom-line impact, ${ }^{122}$ or the plaintiff identifies discriminatory practices at a particular step, a defendant firm can probably demonstrate the business necessity of making work apportionment, salary, or partner decisions based on high billable hour counts, rainmaking talent, "analytical abilities," or other amorphous partnership-quality measures. ${ }^{123}$ The plaintiff may have some real performance issues, such as rude or offensive interpersonal behavior or a substance abuse problem. ${ }^{124}$ Despite some very thoughtful academic contentions that profitability should not equate to justifiability, ${ }^{125}$ the Supreme Court and lower courts, in decisions that followed, have given employers a large ambit of discretion to decide what practices further their "legitimate" business or employment goals. ${ }^{126}$ In Mungin v. Katten Muchin \& Zavis, the D.C. Circuit expressed its intent to avoid "judicial micromanagement of business practices" and specifically held, in the context of a race discrimination suit by a black associate against his law firm for differential work assignments, that "when an employer decides which of several qualified employees will work on a

valuable statistical evidence); Simpson v. Midland-Ross Corp., 823 F.2d 937, 943 (6th Cir. 1987) (rejecting the sample of seventeen people who left the company as the basis for establishing a statistical pattern); Washington v. Elec. Joint Apprenticeship \& Training Comm. of N. Indiana, 845 F.2d 710, 713 (7th Cir.), cert. denied, 488 U.S. 944 (1988) (finding that selections for twenty positions was too small a sample for statistically valid assessment); Sengupta v. Morrison-Knudsen Co., Inc., 804 F.2d 1072, 1075-76 (9th Cir. 1986) (holding that a department of twenty-eight employees was too small to be statistically relevant); but see Bunch v. Bullard, 795 F.2d 384, 395 (5th Cir. 1986) (permitting an inference of discrimination when "twelve of fifteen (or $80 \%$ ) of white applicants for promotion passed the IPMA exams, while only three of thirteen (or 23\%) of blacks passed" because the passing rates were “"markedly disproportionate"); Rivera v. City of Wichita Falls, 665 F.2d 531, 536-37 n.7 (5th Cir. 1982) (allowing disparate impact calculations based on a sample size of thirty-five).

12242 U.S.C. $\S 2000 \mathrm{e}-2(\mathrm{k})(1)(\mathrm{B})(\mathrm{i})(2006)$.

${ }^{123} 42$ U.S.C. $\S 2000 \mathrm{e}-2(\mathrm{k})(1)(\mathrm{A})(\mathrm{i})(2006)$.

${ }^{124}$ See Barnhart v. Pickrel, Schaeffer \& Ebeling Co., L.P.A., 12 F.3d 1382 (6th Cir. 1993) (upholding the termination of an older employee whose declining work performance was probably attributable to alcohol abuse); Morrissea v. DLA Piper, 532 F. Supp. 2d 595, 613 (S.D.N.Y. 2008) (finding that an African American female attorney was appropriately terminated for her "truculent" behavior and repeated personality conflicts with many different lawyers).

${ }^{125}$ See Ian Ayres, Market Power and Inequality: A Competitive Conduct Standard for Assessing When Disparate Impacts Are Unjustified, 95 CALIF. L. REV. 669 (2007).

${ }^{126}$ New York City Transit Auth. v. Beazer, 440 U.S. 568, 587 n.31 (1979). 
U N I V E R S I T Y O F P I T T S B U R G H L A W R E V I E W

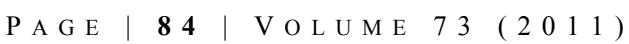

particular assignment.... 'the court must respect the employer's unfettered discretion." 127

\section{Systemic Disparate Treatment}

Systemic disparate treatment cases will encounter many of the same statistical problems as disparate impact suits. ${ }^{128}$ In addition, if a systemic disparate treatment case is not brought as a government enforcement action, a majority of circuits hold that pattern-or-practice suits must satisfy the requirements for a class action and cannot be brought as a theory by an individual plaintiff. ${ }^{129}$ Systemic disparate treatment cases present the same problem of establishing discriminatory intent as do individual disparate cases - only writ large. ${ }^{130}$

Courts also do not seem to insist on rigorous validation of subjective criteria used in high-level promotion decisions for professional jobs. ${ }^{131}$ In Hishon v. King \& Spaulding ${ }^{132}$ the federal district court held that Title VII simply did not apply to law firms' decisions regarding the selection of partners to admit to their partnership.

${ }^{127} 116$ F.3d 1549, 1556 (D.C. Cir. 1997) (quoting Fischbach v. Dist. of Columbia Dept. of Corr., 86 F.3d 1180, 1183 (D.C. Cir. 1996).

${ }^{128}$ See, e.g., Susan Sturm, The Architecture of Inclusion: Advancing Workplace Equity in Higher Education, 29 HARV. J.L. \& GENDER 247, 263-64 (2006). See also Tracy Anbinder Baron, Comment, Keeping Women Out of the Executive Suite: The Courts' Failure to Apply Title VII Scrutiny to UpperLevel Jobs, 143 U. PA. L. REV. 267, 288 (1994) ("In systemic disparate treatment cases, courts often refuse to infer discrimination solely from a pattern of exclusion demonstrated by statistics, and instead insist on anecdotal evidence of discriminatory motive.").

${ }^{129}$ Davis v. Coca-Cola Bottling Co., Consol., 516 F.3d 955, 968 (11th Cir. 2008); Bacon v. Honda of Am. Mfg., 370 F.3d 565, 575 (6th Cir. 2004); Celestine v. Petroleos de Venez. SA, 266 F.3d 343, $355-$ 56 (5th Cir. 2001); Brown v. Coach Stores, Inc., 163 F.3d 706, 711 (2d Cir. 1998); Lowery v. Circuit City Stores, Inc., 158 F.3d 742, 759-62 (4th Cir. 1998), vacated, 527 U.S. 1031 (1999). But see Cox v. Am. Cast Iron Pipe Co., 784 F.2d 1546, 1559 (11th Cir. 1986); Davis v. Califano, 613 F.2d 957, 961-62 (D.C. Cir. 1979); EEOC v. Dial Corp., 156 F. Supp. 2d 926, 946 n.13 (N.D. Ill. 2001) ("pattern-orpractice claims are not subject to Rule 23's requirements"). See also David J. Bross, Note, The Use of Pattern-and-Practice by Individuals in Non-class Claims, 28 NOVA L. REv. 795 (2004) (discussing the circuit split and agreeing with the minority of courts that have not required pattern or practice claims to meet the Rule 23 class action requirements).

${ }^{130}$ Charles A. Sullivan, Disparate Impact: Looking Past the Desert Palace Mirage, 47 WM. \& MARY L. REV. 911, 940 (2005).

${ }^{131}$ Daniel Gyebi, The Civil Rights Act of 1991: Favoring Women and Minorities in Disparate Impact Discrimination Cases Involving High-Level Jobs, 36 How. L.J. 97, 126 (1993).

${ }^{132}$ Hishon v. King \& Spaulding, 24 Fair Emp. Prac. Cas. (BNA) 1303 (N.D. Ga. Nov. 28, 1980), aff'd, 678 F.2d 1022 (11th Cir. 1982), rev'd, 467 U.S. 69 (1984). 
In a very real sense a professional partnership is like a marriage. It is, in fact, nothing less than a "business marriage" for better or worse. Just as in marriage different brides bring different qualities into the union-some beauty, some money, and some character-so also in professional partnerships, new mates or partners are sought and betrothed for different reasons and to serve different needs of the partnership. Some new partners bring legal skills, others bring clients. Still others bring personality and negotiating skills. In both, new mates are expected to bring not only ability and industry, but also moral character, fidelity, trustworthiness, loyalty, personality and love. Unfortunately, however, in partnerships, as in matrimony, these needed, worthy and desirable qualities are not necessarily divided evenly among the applicants according to race, age, sex or religion, and in some they just are not present at all. To use or apply Title VII to coerce a mismatched or unwanted partnership too closely resembles a statute for the enforcement of shotgun weddings. ${ }^{133}$

Although the U.S. Supreme Court ultimately reversed the district court's decision, holding that Title VII applies to partnership decisions, courts give wide latitude to law firms in their partnership selection practices. ${ }^{134}$

Then there is the matter of independent defenses. Although this has not surfaced in published lawyer-versus-law-firm decisions, it takes no stretch of imagination to anticipate firms raising a variation of the EEOC v. Sears, Roebuck $\& C o{ }^{135}$ choice defense: that female attorneys lack interest in the legal equivalent of commission sales jobs, like mergers and acquisitions and other risky propositions. ${ }^{136}$ Just as girls gravitate to the softer side of Sears, maybe lady lawyers like family law. ${ }^{137}$

${ }^{133} I d$. at 1305 .

${ }^{134}$ Hishon, 467 U.S. at $78-79$.

${ }^{135}$ E.E.O.C. v. Sears, Roebuck \& Co., 628 F. Supp. 1264 (N.D. Ill. 1986), aff'd, 839 F.2d 302 (7th Cir. 1988).

${ }^{136}$ Akshat Tewary, Legal Ethics as a Means to Address the Problems of Elite Law Firm Non-Diversity, 12 ASIAN L.J. 1, 4 (2005).

${ }^{137}$ See, e.g., Mary E. O'Connell \& J. Herbie DiFonzo, The Family Law Education Reform Project Final Report, 44 FAM. CT. REV. 524, 545 n.148 (2006) (“Today, women lawyers make up a disproportionate share of the family law bar. A recent statewide bar survey in New Hampshire indicated that domestic relations continues to be the most common legal specialty for women lawyers, with $22 \%$ of all female lawyers, but only $6 \%$ of males, spending $50 \%$ or more of their time practicing family law."). 
U N I V E R S I T Y OF P I T T S B U R G H L A W R E V I E W

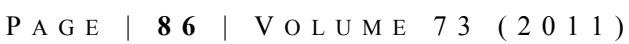

\section{Difficulties With Sexual Harassment}

According to surveys, studies, and anecdotal reports, sexual harassment against female lawyers is rampant. According to one report, between one-half and two-thirds of all female lawyers had experienced some form of sexual harassment at work. ${ }^{138}$ "[W]omen lawyers report they are still referred to as 'baby' and 'sweetie,' called by their first names rather than by their titles, mistaken for legal assistants not lawyers, and subjected to condescending treatment, sexist jokes, and inappropriate comments." "139 The sex discrimination and harassment is not relegated just to women. One survey of attorneys and judges in Arizona showed that almost a third reported a belief "that lesbians and gays were discriminated against in the legal profession."

Sexual harassment suits by attorneys against their firms suffer from many of the same doctrinal hurdles as harassment suits in other occupational categories: plaintiffs may have difficulty establishing that the conduct was sufficiently severe and pervasive to amount to a hostile environment ${ }^{141}$ and even that the conduct was "unwelcome." 142 As in other lines of work, sometimes the conduct does not rise to the level of sufficient severity or pervasiveness. A client of the firm tells a single inappropriately sexual joke. An associate sends a sexually explicit or gender

138 Deborah L. Rhode, A.B.A. Commission on Women in the Profession, The Unfinished Agenda: Women ANd the Legal Profession 19 (2000). See also Jay Marhoefer, Note, The Quality of Mercy Is Strained: How the Procedures of Sexual Harassment Litigation Against Law Firms Frustrate Both the Substantive Law of Title VII and the Integration of an Ethic of Care into the Legal Profession, 78 CHI.-Kent L. ReV. 817, 832 (2003).

${ }^{139}$ Judith S. Kaye \& Anne C. Reddy, The Progress of Women Lawyers at Big Firms: Steadied or Simply Studied?, 76 FORDHAM L. REV. 1941, 1955 (2008).

${ }^{140}$ M.V. Lee Badgett et al., Bias in the Workplace: Consistent Evidence of Sexual Orientation and Gender Identity Discrimination 1998-2008, 84 CHI.-KENT L. REV. 559, 569 (2009).

${ }^{141}$ EEOC v. Robert L. Reeves \& Assoc., No. 00-10515 DT, 2002 WL 1634013, at *7 (C.D. Cal. Feb. 19, 2002), rev'd, 68 Fed. App'x 830 (9th Cir. 2003).

${ }^{142}$ Meritor Savings Bank v. Vinson, 477 U.S. 57, 68 (1986), heralded the high burden of establishing whether particular conduct was indeed unwelcome: "[The burden] presents difficult problems of proof and turns largely on credibility determinations committed to the trier of fact." Lower courts followed suit, holding, for example, that a failure to initially complain about harassing behavior meant that it was not unwelcome, Reed v. Shepherd, 939 F.2d 484, 492 (7th Cir. 1991), that a plaintiff's perception of a defendant rubbing his groin against her as "disgusting and degrading" did not amount to unwelcomeness, Sauers v. Salt Lake City, 1 F.3d 1122, 1124, 1126 (10th Cir. 1993), or that the plaintiff's toleration of a manager's sexual advances out of fear for several years meant that the plaintiff could not establish that they were unwelcome, Hocevar v. Purdue, Frederick Co., 223 F.3d 721, 723-25 (8th Cir. 2000). 
disparaging email. ${ }^{143}$ Proving "unwelcomeness" may be especially problematic for female attorneys who engage in banter to fit into the world of male lawyers. ${ }^{144}$

Many of the other subtleties of sexual harassment law seem particularly pronounced in the case of lawyer plaintiffs and defendants. It may be difficult for a plaintiff who complains about harassment and then is not funneled work and has trouble making the firm's hourly billing requirements to establish the causal connection between the complaint and the retaliation. ${ }^{145}$ Defendant law firms are also savvy enough to know that they can avoid liability for many instances of harassment with an affirmative defense. The first prong of that defense requires employers to use "reasonable care to prevent and correct promptly any sexually harassing behavior." 146 The vast majority of law firms have anti-discrimination and anti-harassment policies in place. "Virtually all law firms, for instance, publish identical-sounding EEO policies with standard promises of equal treatment and assertions of nondiscriminatory decisionmaking. This seems to be enough to protect employers from liability.",147

If harassment does occur, law firms, like other businesses, may try to selfprotect. In an early and celebrated case, Weeks v. Baker \& McKenzie, ${ }^{148}$ a law firm secretary successfully sued a partner and a prominent law firm for sexual harassment for $\$ 50,000$ in compensatory damages and $\$ 3.5$ million in punitive damages. The firm had failed to investigate the conduct of the partner for more than five years, despite complaints from numerous secretaries, and only removed

${ }^{143}$ See, e.g., Julie A. Pace, Harassment, Discrimination \& Retaliation: Time to Audit Your Firm, 44 ARIZ. ATT'Y 10 (Sept. 2007).

${ }^{144}$ Robert L. Reeves \& Assoc., No. CV0010515DT(RZX), 2002 WL 1151459, at*10.

${ }^{145}$ Isaacson v. Keck, Mahin \& Cate, No. 92-c-3105, 1993 WL 68079 (N.D. Ill. Mar. 10, 1993) (finding that the lawyer plaintiff alleged sufficient facts to survive dismissal regarding partners retaliating for her sexual harassment complaint by refusing to give her any work).

${ }^{146}$ Burlington Indus. v. Ellerth, 524 U.S. 742, 765 (1998).

147 Scott A. Moss, Women Choosing Diverse Workplaces: A Rational Preference with Disturbing Implications for Both Occupational Segregation and Economic Analysis of Law, 27 HARV. WOMEN's L.J. 1, 22 (2004). See also Moss \& Huang, supra note 20, at 251-53 (arguing that "courts should examine employer antidiscrimination programs with a critical eye toward their content, not with the deference existing case law appears to grant to just about any sort of 'training."'); but see Pace, supra note 143 , at 10 ("For various reasons, many law firms have been reluctant to develop and implement effective diversity, anti-discrimination and anti-harassment programs. Even though many clients in corporate America long ago established such programs, law firms have felt they are above implementing such programs, and most have not done so or have done so only on paper.").

14874 Cal. Rptr. 2d 510 (Cal. Ct. App. 1998). 
him from the partnership because a paralegal-during her deposition in the harassment lawsuit—-testified that the partner had been backdating documents. ${ }^{149}$

Courts also seem to be protective of law firms regarding discovery of information relevant to whether firms tolerate sexually hostile conduct in the workplace. ${ }^{150}$ Even if a plaintiff leaps through all of the employment discrimination doctrinal hoops, an appellate court may find that the amount of damages awarded against a law firm for a partner's sexual harassment of a first-year associate are excessive. $^{151}$

Finally, even though one might anticipate that lawyers - a more highly educated bunch, particularly about the law-would benefit from sexual harassment training, this may not be the case. A study among lawyers in New York regarding the effects of sexual harassment training showed that the "training made senior male partners wary of interacting with female associates, thus limiting women's mentoring opportunities."

For the most part, the doctrinal analysis in many Title VII cases involving suits against law firms tracks that in cases arising in other employment arenas. As with suits outside the law firm context, plaintiffs may achieve more success with retaliation claims than with the underlying discrimination claims. ${ }^{153}$ Even when discrimination allegations against a law firm fail, as in other areas of employment,

${ }^{149} I d$. at $515-18,520$.

${ }^{150}$ K.S. v. ABC Prof'l Corp., 749 A.2d 425 (N.J. Super. Ct. App. Div. 2000) (imposing a protective order preventing an associate who claimed she was raped by a partner from deposing partners about their sexual relations with other associates or secretaries).

${ }^{151}$ See Sier v. Jacobs Persinger \& Parker, 714 N.Y.S.2d 283 (N.Y. App. Div. 2000) (finding the trial judge's award of $\$ 250,000$ emotional distress damages excessive and reducing the award to $\$ 200,000$ ).

${ }^{152}$ Justine E. Tinkler, "People Are Too Quick to Take Offense": The Effects of Legal Information and Beliefs on Definitions of Sexual Harassment, 33 LAw \& Soc. INQUiRy 417, 426 n.4 (2008) (citing Epstein et al., supra note 93).

153 See, e.g., Collins v. Cohen Pontani Lieberman \& Pavane, No. 04-cv-8983, 2008 WL 2971668 (S.D.N.Y. July 31, 2008) (finding that the plaintiff, a litigator, established a prima face retaliation claim when she complained about the law firm's treatment of female associates); Kinzer v. Fabyanske, Westra \& Hart, P.A., No. 00-cv-855, 2001 WL 1110371, at *4-5 (D. Minn. Sept. 19, 2001) (rejecting an associate's disability discrimination claim against his law firm, but allowing his retaliation claim to proceed because of factual issues regarding the causal connection between the associate's filing of an EEOC charge and his ultimate termination, even in the face of the firm's legitimate concerns about the plaintiff's inability to get along with staff); but see King v. Phelps Dunbar, L.L.P., 844 So. 2d 1012 (La. Ct. App. 2003) (holding that a plaintiff who claimed retaliation by his law firm in the form of poor performance reviews for his refusal refused to take "race-based assignments" was unable to establish a causal link between the evaluations and his refusal of assignments). 
retaliation claims may survive, even on frail evidentiary foundations. ${ }^{154}$ Cumulatively, though, the primary employment discrimination theories under Title VII are exceptionally awkward mechanisms for recovery by lawyers whose firms discriminate against them.

\section{Practical Limits on Suits}

Lawyers suing their law firms also face significant practical impediments to pursuing legal redress. In part it is the perennial employment discrimination problem: that the recovery, given caps on compensatory and punitive damages, is too small to justify the time, expense, and emotional havoc of suing. ${ }^{155}$ That can be aggravated when members of the legal community sue their own: it is the "You'll Never Eat Lunch or File a Brief in This Town Again" phenomenon. ${ }^{156}$ Lawyers may fear that large portions of a legal community will retaliate or be reluctant to hire them. That a lawyer who becomes a plaintiff may damage his or her own career and burn bridges is a critical problem which may mean, as a practical matter, that those who have other options take them.

Apart from the difficulty of finding a plaintiff's attorney willing to take the case against other lawyers, ${ }^{157}$ law firms are unattractive defendants. They are unstable targets. Lawyers change firms; "firms merge, expand and, sometimes, collapse." Law firms are, in the words of one commentator, "tiny, fragile enterprises with virtually no assets beyond their highly mobile professional talent." 158

\footnotetext{
${ }^{154}$ Ullmann v. Olwine, Connelly, Chase, O’Donnell \& Weyher, 123 F.R.D. 237, $248-49$ (S.D. Ohio 1987) (allowing a retaliation claim to survive summary judgment based on the female plaintiff's allegations that she was terminated from her document review job because she, unlike other female lawyers, protested at the flirtatious and inappropriately sexual office behavior).

${ }^{155} 42$ U.S.C. $§ 1981 \mathrm{a}(\mathrm{b})(3)$ (1991). A law firm that has between 15 and 100 employees is liable for a maximum of $\$ 50,000$ in compensatory and punitive damages.

${ }^{156}$ See, e.g., Southern Methodist Univ. Ass'n of Woman Law Students v. Wynne \& Jaffe, 599 F.2d 707, 714 (5th Cir. 1979) (denying association of female law students and several female attorneys who sued a law firm for sex discrimination the ability to proceed anonymously, but limiting distribution and prohibiting disclosure of the membership information beyond the defendant law firm).

${ }^{157}$ See generally Alison Bass, Lawyers Reluctant to Go After Peers, Boston GloBe, Aug. 6, 1995, at 1 (discussing problems of professional courtesy and overlapping insurance carriers).

${ }^{158}$ Anthony Lin, Law Firms' Shallow Pockets Frustrate Lawyers Suing Them, 229 N.Y. L.J. 1, 1 (May 7, 2003).
} 
The bottom line on lawsuits is that employment discrimination law is limited in what it can remedy. Perhaps the most important limitation of all is that the types of things that make lawyers unhappy aren't things that can be remedied in lawsuits.

Associate abuse, in most of its incarnations, is not redressable under employment discrimination laws. There are no reported cases of attorneys suing for excessive billable hour requirements outside the pregnancy or disability contexts. ${ }^{159}$ Law firms are "equal opportunity abusers . . . the firms are brutal on everyone." "160 A range of believable explanations usually exists for differences in treatment - and they have to do with "what it takes to succeed in the supercompetitive world of modern law practice." "161 Even if law firms seem to take advantage of their lawyers by demanding long hours and then remunerating the lawyers for a fraction of the value of their services, this is not conduct remediable under employment discrimination laws. ${ }^{162}$

\section{Alternative AVEnUes Of Legal ReDress}

\section{A. Stretching Title VII}

\section{Comparators}

One doctrinal development that would help all plaintiffs, not just those plaintiffs who are lawyers, would be a revision in the comparator standard. As discussed above, plaintiffs often lose discrimination cases because of their inability to identify an appropriate comparator-someone whose job was closely similar to their own-who was treated more favorably by the employer. ${ }^{163}$ Professor Charlie Sullivan has written convincingly that the lower federal courts impose widely varying standards for acceptance of comparator evidence, often based primarily on either the judges' own perceptions of comparability or latitude given to the

\footnotetext{
${ }^{159}$ Sussman v. Salem, Saxon \& Nielsen, P.A., 818 F. Supp. 1510 (M.D. Fla. 1993) (holding that a law firm requiring a tax attorney with pregnancy complications to bill eight hours a day despite her physician's instructions presented a fact question under the Pregnancy Discrimination Act).

${ }^{160}$ David Segal, The Final Lesson of the Mungin Race Case, WASH. Post, Jan. 11, 1999, at F9.

${ }^{161} I d$.

${ }^{162}$ See, e.g., Dorfman, 2005 WL 1861813, at *5 (rejecting the plaintiff lawyer's age discrimination suit when his only allegations were that he was "hired in order to score a particular account, that he completed a tremendous amount of work in a short period of time with no training and that he did so for a fraction of what Defendant charged for his services. As oppressive as Plaintiff may believe this work environment to have been, his alleged experiences do not implicate the ADEA in any way.").

${ }^{163}$ See supra discussion in text at notes 43-64.
} 
defendant's testimony. ${ }^{164}$ Sullivan wisely proposes a different test for acceptance of comparator evidence-industry standards as articulated by experts: "Rather than looking solely to the judge's own worldviews and experiences, whose accuracy might be legitimately questioned, the appropriate metric should be the reasonableness of the discrepancy in treatment in terms of industry practices." The federal courts, though, seem to be contracting, rather than expanding, their consideration of comparator evidence. ${ }^{166}$

\section{Partners as Employees}

An actual development under Title VII has to do with partners' abilities to sue their firms. Historically, courts did not consider partners in a law firm as employees. ${ }^{167}$ Thus, when Sidley Austin Brown \& Wood demoted thirty-two equity partners over forty years old to essentially "of counsel" positions in $1999,{ }^{168}$ the EEOC took a case in mostly uncharted territory. Writing for the Seventh Circuit and ruling on an evidentiary matter, Judge Richard Posner asked whether the partners had sufficient power in the firm to protect themselves from discrimination. ${ }^{169} \mathrm{He}$ noted that in "a partnership of more than 500 partners in which all power resides in a small, unelected committee" of thirty-six members, the thirty-two demoted partners "were defenseless; they had no power over their fate. ${ }^{\prime 170}$

While the Sidley Austin case wound through the federal courts, in 2003 the Supreme Court decided Clackamas Gastroenterology Associates, P.C. v. Wells, ${ }^{171}$ which changed the landscape. The Supreme Court held that doctors who were directors and shareholders of a medical partnership could also be employees, depending on their extent of control of the partnership, informed by:

${ }^{164}$ Sullivan, supra note 62, at 213-23.

${ }^{165} \mathrm{Id}$. at 224. "This metric should guide judges in the first instance in deciding when cases involving comparators should go to the jury and should guide jurors in the final analysis in deciding whether the more favorable treatment of a comparator justifies the ultimate inference of discrimination." Id.

${ }^{166}$ See supra discussion in text at notes 43-64, 118.

${ }^{167}$ Hishon v. King \& Spalding, 467 U.S. 69, 79 (1984) (Powell, J., concurring).

${ }^{168}$ E.E.O.C. v. Sidley Austin Brown \& Wood, 315 F.3d 696, 698 (7th Cir. 2002).

${ }^{169}$ Id. at $703-04$.

${ }^{170} I d$. at $702-03,704$.

${ }^{171} 538$ U.S. 440 (2003). 
U N I V E R I T Y OF P I T T S B U R G H L A W R E V I E W

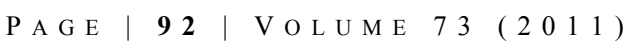

Whether the organization can hire or fire the individual or set the rules and regulations of the individual's work.

Whether and, if so, to what extent the organization supervises the individual's work.

Whether the individual reports to someone higher in the organization.

Whether and, if so, to what extent the individual is able to influence the organization.

Whether the parties intended that the individual be an employee, as expressed in written agreements or contracts.

Whether the individual shares in the profits, losses, and liabilities of the organization. $^{172}$

As law firms expand and create tiers of partnership, "the majority of partners appear more like employees and less like employers." ${ }^{173}$ Whether law firm partners are considered employees, and thus entitled to anti-discrimination protection, may depend less on whether a partner is an equity or non-equity partner ${ }^{174}$ and more on the actual control exercised, even if a partner is an equity partner. The cases decided since Clackamas "place substantial emphasis on a partner's relative power and control within his or her firm.",175

In Kirleis v. Dickie, McCamey \& Chilcote, P.C., ${ }^{176}$ the court held that a law firm equity shareholder and director, who had equal ownership rights with her partners and had a generous package of benefits (such as parking, airfare, a spending allowance, and country club dues) that most employees did not receive, was a statutory employer, rather than employee, and thus could not sue her firm for sex discrimination and a hostile work environment. The plaintiff's claims that she had no real power- that the directors meetings essentially were "'rubber stamps' for decisions already made by the Board of Directors and that non-Executive

172 Id. at 449-50 (quoting U.S. EQUAL EMP'T OPPORTUNITY COMM'N, COMPLIANCE MANUAL $\S 605: 0009)$.

${ }^{173}$ Rachel M. Milazzo, Note, Circular Definitions of What Constitutes an Employee: Determining Whether the Partners of Sidley Austin Brown \& Wood Qualify as Employers or Employees Under Federal Law, 51 ST. LouIS U. L.J. 1329, 1354 (2007).

${ }^{174}$ See Richmond, supra note 35.

175 Jessica Fink, A Crumbling Pyramid: How the Evolving Jurisprudence Defining 'Employee' Under the ADEA Threatens the Basic Structure of the Modern Large Law Firm, 6 HASTINGS BuS. L.J. 35, 36 (2010).

${ }^{176}$ No. 06cv1495, 2009 WL 3602008 (W.D. Pa. Oct. 28, 2009). 
Committee Directors do not meaningfully participate in the Board of Directors meetings"- did not sway the court. ${ }^{177}$

This is an area that may be evolving through law firms' somewhat voluntary changes. In 2007, to settle the age discrimination claims of more than thirty partners forced out by its mandatory retirement age, Sidley Austin entered a \$27 million consent decree with the EEOC that included abolition of its mandatory retirement policy. ${ }^{178}$ This may herald changes in the mandatory retirement policies still in existence in half of law firms with 100 or more lawyers. ${ }^{179}$ Since the Sidley Austin settlement, a number of the largest law firms have announced the end of their compulsory retirement rules. ${ }^{180}$

\section{B. Alternative Federal Theories}

\section{Equal Pay Act}

For gender-based wage discrepancies, Equal Pay Act claims may be easier to pursue in at least one respect because they do not require proving discriminatory intent. ${ }^{181}$ Equal Pay Act claims tend to fail because it is hard to find two lawyers in positions demanding substantially equal skill, effort, and responsibility. Even if lawyers have substantially equal job responsibilities, revenue-generation (or rainmaking) ability is an affirmative defense. ${ }^{182}$ However, there may be a degree of latitude offered to comparators under the Equal Pay Act that does not seem available under Title VII. For example, in Dubowsky v. Stern, Lavinthal, Norgaard

\footnotetext{
${ }^{177} I d$. at $* 14$.

${ }^{178}$ EEOC v. Sidley Austin Brown \& Wood, 406 F. Supp. 2d 991 (N.D. Ill. 2005).

${ }^{179}$ Gary J. Oberstein, Should Law Firms Put to Pasture Age-Based Mandatory Retirement?, 52 BostoN B.J. 14, 14 (June 2008). See also Leigh Jones, ABA Policy, Sidley Austin Settlement Have Firms Rethinking Retirements, 190 N.J. L.J. 645 (Nov. 12, 2007) ("Some 57 percent of law firms with more than 100 attorneys have age-based retirement policies, according to a 2005 survey by Altman Weil. The survey also found that the age of mandatory retirement is between the ages of 65 and 70 , with the majority of firms requiring retirement at 70.”).

${ }^{180}$ Lillian Kim, Comment, Mandatory Retirement in the Private Sector: The Reach (or Inapplicability) of the Age Discrimination in Employment Act Domestically and Abroad, 12 U. PA. Bus. L. 1209, 1228 (2010).

${ }^{181}$ Ledbetter v. Goodyear Tire \& Rubber Co., 550 U.S. 618, 659 (2007) (Ginsburg, J., dissenting) (“The key distinction is that Title VII requires a showing of intent. In practical effect, 'if the trier of fact is in equipoise about whether the wage differential is motivated by gender discrimination,' Title VII compels a verdict for the employer, while the EPA compels a verdict for the plaintiff.").

${ }^{182}$ Byrd, 61 F.3d at 1034 .
} 
$\&$ Daly, ${ }^{183}$ a female lawyer established a prima facie case under the Equal Pay Act when she and her male successor, who was hired less than half a year after her termination and was paid $20 \%$ more than she had been paid, seemed to share "a common core of tasks." "184 The court ruled that whether the plaintiff and her successor had jobs that required the same degree of skill, effort, and responsibility was a jury question. Typically, however, variations in pay based on differences in relevant experience do not constitute violations of the Equal Pay Act. ${ }^{185}$

\section{Family Responsibilities Discrimination}

The terrain may be changing in an important area. One of the newest types of lawsuits is a cause of action for discriminatory treatment of workers based on their family responsibilities. That includes not only pregnancy and "maternal wall" discrimination, but also caregiving by both women and men for children, parents, partners, and spouses. The atmosphere has changed at least somewhat since ten years ago when Deborah Rhode told the story of a female lawyer in Boston who upon return from maternity leave found that her firm gave her only paralegal-type work, and who said, "I had a baby, not a lobotomy.", 186 The Project for Attorney Retention has found thirty-three cases in the past twenty years in which law firm employees (lawyers or support staff) have sued their firms for family responsibilities discrimination. ${ }^{187}$ Courts are demonstrating increasing sensitivity to gendered comments relative to pregnancy discrimination. ${ }^{188}$ Depending on the facts, these cases may be brought under Title VII, the Americans with Disabilities

${ }^{183} 922$ F. Supp. 985 (D. N.J. 1996).

${ }^{184} I d$. at 990.

${ }^{185}$ Knadler v. Furth, 253 F. App’x 661, 664 (9th Cir. 2007).

${ }^{186}$ Deborah L. Rhode, Myths of Meritocracy, 65 FORDHAM L. REV. 585, 588 (1996); see also DEBORAH L. Rhode, Balanced lives: Changing the Culture of Legal Practice, American Bar Ass'N COMM'N ON WOMEN IN THE PROFESSION 16 (2001), available at http://womenlaw.stanford.edu/ balanced.lives.pdf.

187 Joan Williams et al., Law Firms as Defendants: Family Responsibilities Discrimination in Legal Workplaces, 34 PEPP. L. REV. 393, 395 (2007). "[T]he Center for WorkLife Law at the University of California, Hastings College of the Law has identified over eight hundred FRD cases filed against employers since the 1970 s using seventeen different legal theories under existing state and federal law." Id. at 396.

${ }^{188}$ See, e.g., Sigmon v. Parker Chapin Flattau \& Klimpl, 901 F. Supp. 667 (S.D.N.Y. 1995) (admitting evidence about the high number of pregnant women who left the corporate department, recognizing that a partner's comment "With all these pregnant women around, I guess we should stop hiring women" indicated potential discriminatory intent, and permitting the inference that the plaintiff's diminished billable hours following her maternity leave might be attributable to isolating activities by the firm rather than any performance issues on the plaintiff's part). 
Act, ${ }^{189}$ the Family and Medical Leave Act, ${ }^{190}$ and various other state and federal laws. $^{191}$

\section{State Employment Law, Tort and Contract Theories}

Employment discrimination law is not the only avenue for redress of lawyer grievances against their law firms. There may also be claims under county or city antidiscrimination ordinances, ${ }^{192}$ suits under state common law wrongful discharge principles, ${ }^{193}$ or partnership contract claims such as breach of fiduciary duties or covenants of good faith and fair dealing. ${ }^{194}$ As just one example, an in-house lawyer reported her employer's general counsel to the state disciplinary board for not being licensed to practice in the state and the general counsel subsequently retaliated by terminating her. The Tennessee Supreme Court held that the terminated lawyer stated a viable common-law cause of action for retaliatory discharge. ${ }^{195}$ Other discrimination suits may be styled as suits for breach of a partnership agreement, ${ }^{196}$ contact breaches for failure to pay agreed-upon commissions, ${ }^{197}$ or plain-vanilla common-law torts, such as defamation ${ }^{198}$ and negligent or intentional infliction of emotional distress. ${ }^{199}$ As with emotional

18942 U.S.C. $\S$ 1201-12213 (2008).

${ }^{190} 29$ U.S.C. $\S \S 2601-2654$ (2008).

191 See Joan C. Williams \& Stephanie Bornstein, The Evolution of "FReD": Family Responsibilities Discrimination and Developments in the Law of Stereotyping and Implicit Bias, 59 HASTINGS L.J. 1311 (2008).

${ }^{192}$ See, e.g., Frank and Freedus v. Allstate Ins. Co., 45 Cal. App. 4th 461 (1996).

${ }^{193}$ See, e.g., Brown v. Hammond, 810 F. Supp. 644 (E.D. Pa. 1993); Jacobson v. Knepper and Moga, P.C., 688 N.E.2d 813 (Ill. App. Ct. 1997); Pane v. Goffs, 904 N.E.2d 801 (Mass. App. Ct. 2009); Molesworth v. Brandon, 672 A.2d 608 (Md. 1996).

${ }^{194}$ See Dowley v. Dewey Ballentine, LLP, No. 05-622 (EGS), 2006 WL 1102768 (D.D.C. Apr. 26, 2006).

${ }^{195}$ Crews v. Buckman Labs Int'l, Inc., 78 S.W.3d 852 (Tenn. 2002); but see Balla v. Gambro, Inc., 584 N.E.2d 104, 107-08 (Ill. 1991) (holding that whistleblowing in-house counsel could not bring a claim for retaliatory discharge).

${ }^{196}$ Levy v. Schnader, Harrison, Segal \& Lewis, 648 N.Y.S.2d 572 (N.Y. App. Div. 1996).

197 See Collins v. Cohen Pontani Lieberman \& Pavane, No. 04CV8983 (KMW) (MHD) 2008 WL 2971668 (S.D.N.Y. July 31, 2008).

${ }^{198}$ Mittelman v. Witous, 552 N.E.2d 973 (Ill. 1989).

${ }^{199}$ But see Ranciato v. Saxe Doernberger \& Vita, P.C., No. CV030478651S, 2004 WL 2444153 (Conn. Super. Ct. Oct. 5, 2004). Ranciato was framed as a suit for negligent and intentional infliction of emotional distress. The facts entailed inappropriate comments that implied the plaintiff was promiscuous, had more extensive work assignments than comparable males, was subjected to 
distress suits in other contexts, courts seem to require persistent patterns of conduct. $^{200}$

All of these state claims are subject to particular proof problems. Defamation claims, for example, if based on statements about a lawyer's poor performance, may be nonactionable as an expression of opinion. ${ }^{201}$ Or any partners' statements about an attorney's performance to others in the partnership may be protected as intracorporate communications. ${ }^{202}$ Or attorneys may be at-will employees to whom the state's wrongful discharge laws do not apply. ${ }^{203}$

Attorneys may have better claims under state than federal antidiscrimination laws. For instance, in Davis v. Levy, Angstreich, Finney, Baldante, Rubenstein \& Coren, P.C., the court allowed an associate to sue individual partners of a law firm for disability discrimination under the Pennsylvania Human Rights Act, while a similar claim would not be allowed to proceed under federal statutes. ${ }^{204}$

A number of state antidiscrimination statutes have a lower threshold for the number of employees than Title VII's fifteen, ${ }^{205}$ and thus may provide expanded protection for lawyers working in smaller firms. Similarly, although the minimum

humiliating teasing, was excluded from lunches, was ignored when attempting to communicate, saw her name removed from cases she was working on. The court concluded:

There is no question that the acts of which the plaintiff complains if proven were crude, obnoxious, boorish, inappropriate and insensitive, committed in an atmosphere supposed to be dominated by professionalism. While these alleged acts were upsetting and embarrassing to the plaintiff, they do not rise to the level required to sustain a legally sufficient claim for intentional infliction of emotional distress.

Id. at 5. Even if a law firm discriminatorily discharges an attorney, employment discrimination alone does not rise to the level of outrage required by the intentional infliction of emotional distress tort. Sigmon, 901 F. Supp. 667.

${ }^{200}$ See Knadler v. Furth, 253 F. App’x 661, 665 (9th Cir. 2007) (holding that a single incident of a purportedly racially discriminatory comment was insufficient to establish the tort of intentional infliction of emotional distress).

${ }^{201}$ See Kronenberg v. Baker \& McKenzie LLP, 692 F. Supp. 2 d 994 (N.D. Ill. 2010); Silverman v. Clark, 822 N.Y.S.2d 9 (N.Y. App. Div. 2006); Miller v. Richman, 592 N.Y.S.2d 201 (N.Y. App. Div. 1992).

${ }^{202}$ See Blake v. May Dep’t Stores Co., 882 S.W.2d 688 (Mo. Ct. App. 1994).

${ }^{203}$ Weintraub v. Phillips, Nizer, Benjamin, Krim, \& Ballon, 568 N.Y.S.2d 84 (N.Y. App. Div. 1991).

20420 F. Supp. 2d 885 (E.D. Pa. 1998).

205 See, e.g., Mo. AnN. STAT. § $213.010(7)$ (West 2010) (six or more employees); N.M. STAT. ANN. $\S$ 28-1-2(B) (West 2009) (four or more employees); WASH. REV. CODE § 49-60-040(11) (2009). 
age for Age Discrimination in Employment Act protection is forty, ${ }^{206}$ some state statutes protect younger employees. ${ }^{207}$ In addition, states may protect against discrimination based on status or identity categories not protected under federal statutes, such as sexual orientation or being a breastfeeding mother or domestic violence victim. ${ }^{208}$ State statutes may afford more expansive remedies by not capping or limiting damages. ${ }^{209}$

Claims and remedies available under state antidiscrimination statutes may be more expansive than those possible under federal statutes. Certainly some suits by lawyers against their law firms are justifiable; a number may even be viable. But are there other, better ways to make lawyers happy?

\section{Finding HAPPiness OUTSIDE OF EMPLOYMENT DISCRIMINATION LAW}

By the time lawyers are contemplating suits against their law firms, communication has probably broken down to an irreparable degree. As with discrimination and dissatisfactions in other jobs, it is much better to think in terms of prevention rather than cure. These prophylactic activities fall into two primary categories: things lawyers can do to make themselves happier in their careers and things law firms can do to make their attorneys happier. ${ }^{210}$

\section{A. Attorney Self-Help Toward Happiness}

This section focuses briefly on what lawyers can do individually to find more satisfaction in their careers. While satisfaction among attorneys has a strong correlation with a number of variables-age, race, sex, firm size, and type of

${ }^{206} 29$ U.S.C. $\S 631$ (2008).

${ }^{207}$ See, e.g., IOWA CODE ANN. § 216.6(3) (West 2009) (covering individuals who are at least eighteen years of age); MinN. STAT. ANN. § 363A.03(2) (West 2004) (protecting from age discrimination people who are at least twenty-five years of age).

${ }^{208}$ See Sandra Sperino, Judicial Preemption of Punitive Damages, 78 U. CIN. L. REV. 227, 238 (2009).

${ }^{209}$ Compare 42 U.S.C. $\S 1981$ a(b)(3) (2006) (setting forth caps for compensatory and punitive damages under Title VII, ranging from $\$ 50,000$ for employers with fewer than 101 employees to $\$ 300,000$ for employers with more than 500 employees), with Brady v. Curators of Univ. of Mo., 213 S.W.3d 101, 111 (Mo. Ct. App. 2006) (noting that punitive damages are not capped under the Missouri Human Rights Act).

${ }^{210}$ We have addressed elsewhere some of the things law schools can do to prepare students to be happier lawyers. See Nancy Levit \& Douglas O. Linder, Happy Law Students, Happy Lawyers, 58 SYRACUSE L. REV. 351 (2008). 
U N I V E R S I T Y O F P I T T S B U R G H L A W R E V I E W

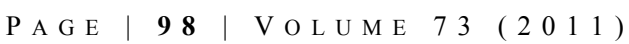

practice $^{211}$ — the parameters of happiness may also be determined, at least in part, by internal personality traits. Researchers think that people have happiness "setpoints" to which they naturally return following emotional fluctuations. ${ }^{212}$ Yet these set-points may not be as fixed as happiness experts thought even five years ago.

Recently, however, an empirical test of set-point theory demonstrates that it may have serious flaws. German Socio-Economic Panel longitudinal survey data from 1984 to 2008 showed that a significant proportion of Germans experienced long-term and ostensibly permanent changes in their overall life satisfaction judgments. ${ }^{213}$ The researchers concluded that people can influence their long- and medium-term overall life satisfaction judgments by their choices and preferences concerning a healthy lifestyle, leisure versus working hours, life goals/priorities, life partner, religion, and social participation. ${ }^{214}$

Attorneys can do a variety of things to make themselves happier. These range from trying simply to do more of the kind of work they like and less of what they don't like ${ }^{215}$ to engaging in more pro bono work $^{216}$ to exploring the prospects at their own firms for greater control. Even in a relatively depressed economic market, many lawyers are looking for different jobs more suited to their individual interests and lifestyle wishes. ${ }^{217}$ The onus of leaving one firm for another has diminished markedly over the past couple of decades. Eighty-five percent of

\footnotetext{
${ }^{211}$ See NANCy Levit \& Douglas O. Linder, The Happy LaWyer: MAKING a GoOd LifE In the LAW (2010).

${ }^{212}$ See generally DAVID T. LyKKEn, HAPPINESS: What Studies On Twins Show Us ABout NATURE, Nurture, And the Happiness Set Point (1999); Daniel Nettle, Happiness: The Science Behind YOUR SMILE 109-12 (2005).

${ }^{213}$ Bruce Headey, Ruud Muffels \& Gert G. Wagner, Long-Running German Panel Survey Shows That Personal and Economic Choices, Not Just Genes, Matter for Happiness, 107 PROC. NAT. ACAD. SCI. 17922 (Oct. 2010), available at http://www.pnas.org/content/107/42/17922.full.pdf+html.

${ }^{214} \mathrm{Id}$. I am indebted to Peter Huang for this point.

${ }^{215}$ See LEVIT \& LINDER, supra note 211, at 70-73.

${ }^{216}$ See id. at 196-97, 228-30.

${ }^{217}$ Associate Satisfaction, 09-5 PARTNER'S ReP. 6 (May 2009) (“Between their second and seventh years of practice, 58 percent of the lawyers [in the After the J.D.'s study of 4,100 lawyers] changed jobs.").
} 
lawyers will change jobs at least once. ${ }^{218}$ The average is to change jobs about three times over the course of a career. ${ }^{219}$

Individually, many lawyers are learning how to develop resilience, a quality that researchers say is one of the best predictors of life satisfaction. Psychiatrist George Vaillant did one of the longest longitudinal studies relating to happiness. It began by studying a class of healthy Harvard sophomores from the early 1940s and it has followed them for almost seventy years. ${ }^{220}$ One of the key findings of this study was that the folks who had happier lives had developed resilience- the ability to put things in perspective and to bounce back after disappointment. Vaillant concluded that the ability to develop mature adaptations to setbacks is one of the best predictors of success and happiness in life. ${ }^{221}$

Some attorneys are also discovering that in law, as with many other professions, satisfaction increases over the course of a career. Lawyers who have been in practice longer tend to be more satisfied with their lives and their careers than newer lawyers. They have developed competencies, arranged their lives to do more of the things they like, and have developed mature adaptations to life's inevitable frustrations. The studies are consistent in finding that lawyers who had practiced longer reported more satisfaction with their careers than newer lawyers. ${ }^{222}$ But rather than waiting for their lawyers to mature into greater life satisfaction, there are things that law firms can do collectively to give their lawyers more satisfaction.

\section{B. Law Firms Making Happier Lawyers}

What can firms do to make their lawyers happier? Law firms are beginning to understand that their primary resources are their lawyers. If those lawyers are unhappy, many of them - particularly the most talented who have other optionswill leave. Firms are also beginning to understand that disenchantment in the

\footnotetext{
${ }^{218}$ Monahan \& Swanson, supra note 16, at 2.

${ }^{219} \mathrm{Id}$.

${ }^{220}$ Joshua Wolf Shenk, What Makes Us Happy?, AtLANTIC, June 2009, at 36, available at http://www.theatlantic.com/magazine/archive/2009/06/what-makes-us-happy/7439/. There was some turnover among the researchers.

${ }^{221} I d$.

${ }^{222}$ See Susan Daicoff, Lawyer, Be Thyself: An Empirical Investigation of the Relationship Between the Ethic of Care, the Feeling Decisionmaking Preference, and Lawyer Wellbeing, 16 VA. J. SOC. POL'Y \& L. 87, 105 n.118 (2008); Heinz et al., supra note 5, at 7-8.
} 
U N I V E R S I T Y O F P I T T S B U R G H L A W R E V I E W

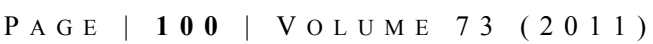

workplace is infectious. $^{223}$ A dimension that has only recently commanded attention is the economic consequences of dissatisfaction.

\section{The Economics of Lawyer Happiness for Law Firms}

In any given year, law firms lose almost $20 \%$ of their associates. ${ }^{224}$ Almost two-thirds of associates will leave their firms before their fifth year of practice. ${ }^{225}$ The economic costs to law firms - estimated at between $\$ 200,000$ to $\$ 500,000$, or approximately twice the lawyer's salary ${ }^{226}$ - are compounded by costs of productivity loss, morale drop, and instability. When lawyers leave, firms lose the investment in the training they have provided, as well as the skills, contacts, and possibly clients the departing lawyers may take with them. ${ }^{227}$

The converse is true as well. When lawyers stay at their firms - and stay satisfied - that has positive economic consequences for firms. Happier workers are more productive. Various experimental studies confirm that happier people perform better on tasks. For instance, one experiment conducted on white-collar workers in a "piece rate" setting demonstrates that after experiencing a happiness-inducing event (watching short comedy routines), subjects exhibited "a highly significant increase in effort" on math problems. ${ }^{228}$ The researchers, professors of behavioral science from Warwick University, concluded that happier workplaces hold the promise to raise the productivity of workers. Other researchers have shown that positive emotions encourage innovations and creative problem solving. ${ }^{229}$ Job

${ }^{223}$ See Kim S. Cameron et AL., Positive Organizational Scholarship: Foundations of A NeW DisciPLINE (2003); Sigal G. Barsade, The Ripple Effect: Emotional Contagion in Groups, 47 ADMIN. SCI. Q. 644 (2002); Joanne H. Gavin \& Richard O. Mason, The Virtuous Organization: The Value of Happiness in the Workplace, 33 ORG. DYNAMICS 379 (2004).

${ }^{224}$ Jones, supra note 6.

${ }^{225}$ Leslie Larkin Cooney, Walking the Legal Tightrope: Solutions for Achieving a Balanced Life in Law, 47 SAN DIEGO L. REV. 421, 438 (2010).

226 Michael Renetzky, The Smart Choice for Large Law Firms, WeST LEgALEdCENTER, http://westlegaledcenter.com/prm/prmJSF.jsf?id=5085614 (last visited Aug. 31, 2011).

227 Joan Williams \& Cynthia Thomas Calvert, Balanced Hours: Effective Part-Time Policies for Washington Law Firms: The Project for Attorney Retention, Final Report, Third Edition, April 2002, 8 WM. \& MARY J. WOMEN \& L. 357, 366 (2002).

${ }^{228}$ ANDREW J. OSWALD ET AL., INST. FOR THE STUdy OF LABOR, HAPPINESS AND PRODUCTIVITY (2009), available at http://149.132.120.83/web/pdf/iniziative/proto.pdf.

${ }^{229}$ See, e.g., Alice M. Isen, Positive Affect and Decision Making, in HANDBoOK of EMOTIONS 417 (Michael Lewis \& Jeannette M. Haviland-Jones eds., 2d ed. 2000); Alice M. Isen et al., Positive Affect Facilitates Creative Problem-Solving, 52 J. PERSONALITY \& SOC. PSYCHOL. 1122 (1987). 
satisfaction correlates with a number of measures of worker productivity. ${ }^{230}$ In addition, both job satisfaction and job dissatisfaction are contagious, ${ }^{231}$ so for law firms, creating a coterie of satisfied workers can have ripple effects. Recognition of the economic and psychological consequences of keeping lawyers happy - and thus keeping them-has prompted some firms to take programmatic steps toward retention.

\section{Retention Projects}

A number of firms across the country are recognizing the importance of attorney retention and are implementing specific policies and programs designed to keep their good lawyers. One of those adaptations is a response to calls by lawyers for greater flexibility in their hours as well as requests for reduced or balanced hours. ${ }^{232}$

Most lawyers would like to work fewer hours than they do. About half of supervised lawyers in a law firm setting would be willing to take reduced compensation in exchange for less time at work. ${ }^{233}$ One interesting set of statistics is that although $98 \%$ of the 1,500 law firms surveyed in 2008 reported that they allow reduced hour work schedules, fewer than $6 \%$ of lawyers actually work parttime. ${ }^{234}$ The vast majority of those who do are women. ${ }^{235}$

Numerous reasons exist for this disparity between the possibility and the reality of reduced hour work. First, attorneys may simply be unaware that the

${ }^{230}$ See Thomas A. Wright \& Barry M. Staw, Affect and Favorable Work Outcomes: Two Longitudinal Tests of the Happy-Productive Worker Thesis, 20 J. ORG. BEHAV. 1 (1999).

${ }^{231}$ See LEVIT \& LINDER, supra note 211, at 116-17, 163-64.

${ }^{232}$ Margaret Heffernan maintains that firms actually harm themselves by having lawyers work such long hours. She argues that virtually every industry, except the professional service industries, has come to the conclusion that beyond 40 hours a week, the quality of work begins to decline. See Debra Cassens Weiss, Why Lawyers Should Work No More than 40 Hours a Week, A.B.A. J. (Aug. 11, 2010, 6:44 AM), http://www.abajournal.com/weekly/article/why_lawyers_should_work_no_more_than_40_ hour_a_week.

${ }^{233}$ Look Beyond Pay Hikes to Enhance Lawyer Satisfaction, 6 COMPENSATION \& BENEFITS FOR L. OFFs. 1 (May 2006).

${ }^{234}$ Martin Vogel-Short, Part-Time Lawyers Still a Tiny Minority and Three Quarters Are Women, Survey Says, 195 N.J. L.J. 23 (2009), available at http://www.law.com/jsp/article.jsp?id= 1202427138453.

${ }^{235}$ Press Release, Nat'l Ass'n for Law Placement, Few Lawyers Work Part-Time, Most Who Do Are Women (Dec. 7, 2006), http://www.nalp.org/ 2006fewlawyersworkpart-time (“[M]ost lawyers working part-time are women-women represented $72 \%$ of partners working part-time and $89 \%$ of associates working part-time."). 
option exists. One study showed that "although ninety-three percent of managing partners said that their firms allow attorneys to work reduced hours, only fifty-nine percent of the supervised attorneys were aware of or thought this a viable option." ${ }^{236}$ Second, attorneys may think — and this has some foundation - that their prospects for job advancement will be diminished if they do something other than the standard partnership track. ${ }^{237}$

The call for reduced or "balanced" hour models is also coming from the new generation of attorneys entering the workforce. In 2007 a group of law students from Stanford and other top schools sent letters to prestigious law firms across the country urging them to reduce billable hour expectations, implement balanced hour policies, and make work expectations transparent by publicizing the median hours associates and partners work. They encouraged firms to lower the expected number of billable hours per year, to move toward flat rate billing, and to allow associates to do more pro bono work. ${ }^{238}$ Since then, the group, Law Students Building a Better Legal Profession (BBLP), has constructed a website that offers an interactive "report card" on more than three hundred firms in eleven major markets based on how compatible firms' policies are with a balanced life for associates. ${ }^{239}$ The next generation in the legal profession may envision and build a much more lawyerfriendly workplace structure.

Retention projects that offer flexibility in working hours and locations feed back into the economic considerations for law firms. Large companies that have adopted flexible work policies have demonstrated savings of tens of millions of dollars in diminished attrition costs. ${ }^{240}$ The advantages of these models from other industries apply in law as well. In the age of laptops, smart phones, online legal

\footnotetext{
${ }^{236}$ Michael A. Scaperlanda, Lawyering in the Little Way of St. Therese of Lisieux With Complete Abandonment and Love, 46 J. CATHOLIC Legal StUd. 43, 48 (2007) (citing SUSAN SAAB ForTNEY, IN Pursuit of AtTorney Work-Life BAlanCe: Best Practices in MANAgEMENT at 94, 109 (2005)).

${ }^{237}$ Some evidence shows that both female and male attorneys who take advantage of reduced hour policies may be viewed as less committed or competent than those who do not. Williams \& Bornstein, supra note 191, at 1329-30. See also Theresa M. Beiner, Not All Lawyers Are Equal: Difficulties that Plague Women and Women of Color, 58 SYRACUSE L. REV. 317, 326 (2008).

${ }^{238}$ Mission Statement, BuILDing A BeTter Legal Profession, http://www.betterlegalprofession.org/ mission (last visited Sept. 3, 2011).

${ }^{239} I d$.

240 "Deloitte \& Touche has estimated that its flexible work arrangements saved \$13 million in 1997 due to reduced attrition. Ernst \&Young, LLP, conservatively estimates that it saved over $\$ 25$ million in 2001 as a result of its efforts that focus on work/life integration and gender issues in the firm." Williams \& Calvert, supra note 227, at 367.
} 
research, and ever-expanding wireless internet access across the world, the telecommuting model should be increasingly available to attorneys. Client meetings, court appearances, and some attorney conferences still necessitate physical presence, but to the extent that a lawyer's primary job is to read, think, and write, this does not need to be done in an office. When law firms offer alternative work schedules that permit part-time or flexible work arrangements, this correlates with higher associate retention. ${ }^{241}$

\section{Movement Away From the Billable Hour Model}

Billable hours create an environment where firms make money by encouraging associates to bill more hours. This system disadvantages anyone with family responsibilities and makes law firms unpleasant places to work. The current economy is likely to increase pressures within firms to have the remaining associates bill more hours and to increase competition among them for remaining jobs at the same time that clients would prefer to cut expenses. Over the years, numerous lawyers and scholars have implored law firms to offer alternative billing arrangements to clients. ${ }^{242}$ The calls for change are coming from a variety of quarters - not just from lawyers who would like time with their families, but also from clients who prefer flat rate (per project) billing, the American Bar Association (which urged lawyers in 2002 to rethink the billable hour), and from students who will be the next generation of lawyers. ${ }^{243}$

Some of that is happening as clients, such as insurance companies, create specific budgets for litigation. ${ }^{244}$ But on their own, some firms are moving to flat or fixed-fee billing. Tucker, Ellis \& West, a 160-lawyer firm in Cleveland, is doing what it can to move away from billable hours. Tucker Ellis derives more than $60 \%$ of its revenue from billing arrangements other than by the hour and that percentage

\footnotetext{
${ }^{241} I d$.

${ }^{242}$ See, e.g., Scott Turow, The Billable Hour Must Die, A.B.A. J., Aug. 2007, at 32, available at http://www.abajournal.com/magazine/article/the_billable_hour_must_die/.

${ }^{243}$ See, e.g., id.

${ }^{244}$ See generally Gary R. Garrett, A Summary for Lawyers and Litigation Support Companies, 23 OF COUNSEL 5 (Dec. 2004) (highlighting efforts by clients to exercise greater oversight and control over their legal services).
} 
has grown each year. ${ }^{245}$ The firm's philosophy is that "Clients want to pay us for what we do, not how long it takes us to do it.",246

As a longer-term trend, law firms are likely to adopt pricing structures other than billable hours, and these newer models may also promote lawyer satisfaction. Client and market pressures, the economics of attorney retention, and the competitive and quality of life advantages of having a workplace where attorneys are satisfied may prompt some firms to implement some form of retention project. Self-regulation, though, has its limits. ${ }^{247}$ Historically, law firms have treated attorney satisfaction as a matter of pure economics: they have tried to retain their most lucrative lawyers with financial inducements to stay. The question is whether firms, which usually come out on the victorious (although perhaps tarnished) side of discrimination lawsuits by their lawyers ${ }^{248}$ but which understand the economic and psychological impact of lawyer dissatisfaction, have sufficient impetus to make more sweeping cultural changes.

\section{Changing the Law Firm Culture}

Anti-discrimination lawsuits cannot really reform most problems of lawyer dissatisfaction because that unhappiness goes to the heart of the current firm model. Law firm culture historically, and still for the most part, is an up-or-out system that, by definition, will exclude some. The firm partnership model is one designed to produce hierarchy. ${ }^{249}$ Failure becomes predictable from the model, and the process itself produces unhappiness even for those who are successful within its terms. ${ }^{250}$ This system - an exclusion rather than inclusion model-disproportionately excludes anyone who is different, particularly women and minorities.

${ }^{245}$ Email from Joseph Morford to author (Oct. 29, 2010, 12:30 PM) (copy on file with author).

246 Stephen C. Ellis, On Being a Happy (and Successful) Lawyer, Remarks at the Commencement Exercises for the Class of 2008 Case Western Reserve University School of Law, May 19, 2008, Cleveland, Ohio, at 4 (copy on file with author).

${ }^{247}$ See Paul M. Secunda, Regoverning the Workplace: From Self-Regulation to Co-Regulation, 64 INDUS. \& LAB. REL. REV. 203, 204 (2010) (book review) (noting that when companies are concerned only about economics or reputational costs, they undertake fixes that are just opportunistic and that ultimately hurt workers in the long run).

${ }^{248}$ See supra text accompanying notes $42-162$.

${ }^{249}$ See Marc Galanter \& William Henderson, The Elastic Tournament: A Second Transformation of the Big Law Firm, 60 STAN. L. REV. 1867, 1881 (2008).

${ }^{250} I d$. at $1896-1900$. 
Many lawyers, especially parents with family responsibilities and those who are different from the dominant group, may find it more difficult to succeed in law practice. To what extent should anti-discrimination law address these concerns? Anti-discrimination law was originally designed to address intentional discrimination. $^{251}$ It can also help identify practices with a disparate impactalthough the idea of a neutral rule or policy with differential effects is problematic in its application to the situations of lawyers because of the enormous variety in lawyers' cases and responsibilities. ${ }^{252}$ Anti-discrimination law is unlikely to lead directly to the production of greater job satisfaction for lawyers because lawyers do not have viable causes of action for many of the most important things that make them unhappy. ${ }^{253}$ In some extreme circumstances, ${ }^{254}$ anti-discrimination litigation can play an important role; in a much larger number of cases, it can't and probably shouldn't. Also, in many cases, the line between actionable discrimination, unconscious bias, ${ }^{255}$ personal dislike, and justifiable perception of a lack of success is thin. Ultimately, litigation is not a particularly good way of addressing the issues most likely to make attorneys unhappy in the modern firm.

Perhaps more relevant to the lives of working lawyers, antidiscrimination law can help systematize good ideas, such as harassment complaint procedures, or to play an important role in helping to create norms, as with some of the maternal wall efforts. ${ }^{256}$ Some law firms, particularly smaller ones, are beginning to realize that there are alternative models out there that can lead to lawyer inclusion and success. ${ }^{257}$ Even larger firms are beginning to pay attention to the economics of

${ }^{251}$ Civil Rights Act of 1991, Pub. L. No. 102-166, § 3, 105 Stat. 1071 (1991).

${ }^{252}$ See supra text accompanying notes $43-53$.

${ }^{253}$ See LEVIT \& LINDER, supra note 211, at 49-67.

${ }^{254}$ See supra text accompanying notes $112-13$.

${ }^{255}$ See, e.g., Jerry Kang \& Kristin Lane, Seeing Through Color Blindness: Implicit Bias and the Law, 58 UCLA L. Rev. 465 (2010); Linda Hamilton Krieger \& Susan T. Fiske, Behavioral Realism in Employment Discrimination Law: Implicit Bias and Disparate Treatment, 94 CALIF. L. REV. 997, 1000 (2006).

${ }^{256}$ See Cooney, supra note 225, at $440 \mathrm{n} .108$ ("Of the FRD [family responsibilities discrimination] cases that have been brought in the legal setting, the situations have resulted from unequal distribution of cases and biased reviews after pregnancy, lack of advancement after motherhood, stigma from part-time schedules or temporary leaves, and traditional gender stereotyping roles .... Over the last decade, FRD lawsuits have increased over $400 \%$ compared to the decade prior."). See generally Williams et al., supra note 187 (discussing recommended considerations for employers).

${ }^{257}$ One point of comparison is to law schools and academic support programs. No law school views as acceptable an admissions process that too disproportionately flunks out women or minorities. See, e.g., 
attorney satisfaction. ${ }^{258}$ The law firms that have been most successful in retaining newer lawyers have adopted structural reforms that provide training, feedback, mentoring, and transparency. ${ }^{259}$

The process of changing the norms and culture at law firms is seismically slow. But the knowledge that other models exist that allow alternative work schedules, different billing arrangements, and even playful workplaces, ${ }^{260}$ is beginning to proliferate. Ways to do things differently are being discussed at conferences and on the internet. ${ }^{261}$ Hopefully, those discussions can come insideinto law firm management meetings - to help make law firms of the future more economically resilient, as well as places lawyers want to work.

Melissa J. Marlow, It Takes a Village to Solve the Problems in Legal Education: Every Faculty Member's Role in Academic Support, 30 U. ARK. LitTLE Rock L. ReV. 489, 498-99 (2008).

${ }^{258}$ See, e.g., Audrey J. Lee, Negotiating Part-Time Work: An Examination of How Attorneys Negotiate Part-Time Arrangements at Elite Law Firms, 6 PEPP. DisP. ReSOL. L.J. 405, 413-14 (2006) ("The Managing Partner of Arnold and Porter, James J. Sandman, offered the business case for effective parttime programs at a 2002 American Bar Association meeting. Sandman argued that an accessible, parttime program enables firms to compete both in the market for talent and for clients: recruits appreciate the option to attempt to balance work and personal needs and clients appreciate committed attorneys who are sometimes better able to focus on their cases because they are assigned to fewer of them.").

${ }^{259}$ See LEVIT \& LINDER, supra note 211, at 173-82.

${ }^{260}$ See id. at 197-99. See also BuILDing A BetTER Legal Profession, http://www.betterlegal profession.org/ (last visited Sept. 3, 2011).

${ }^{261}$ See, e.g., Rachel Breitman, Lawyers, Pros Say Flex Schedule's Time Has Come, THE Am. LAw DAILY (July 17, 2008, 6:47 PM), http://amlawdaily.typepad.com/amlawdaily/2008/07/is-the.html; Center for the Study of the Legal Profession, GeORGETOwn LAw, http://www.law.georgetown.edu/ legalprofession (last visited Sept. 3, 2011) (listing a past event entitled Welcome to the Future: Trends in the Delivery of Corporate Legal Services); Melissa McClenaghan Martin, Law Firms Create New Models for Diversity, LAWJOBS.COM, http://www.lawjobs.com/newsandviews/LawArticle.jsp?id= 1202423389860\&slreturn=1\&hbxlogin=1 (last visited Sept. 3, 2011); Jason Mendelson, Law Firm 2.0 What might the future of law firms look like?, http://www.jasonmendelson.com/wp/archives/2009/04/ law-firm-20-what-might-the-future-of-law-firms-look-like.php (last visited Sept. 3, 2011); Ralph H. Palumbo, Creating the Law Firm of the Future, http://www.summitlaw.com/PalumboArticle.pdf (last visited Sept. 3, 2011). 